University of Louisville ThinkIR: The University of Louisville's Institutional Repository

Electronic Theses and Dissertations

$5-2019$

\title{
Brazilian rhythms on the drum set: stylizations of baiao, frevo and maracatu by drummers Airto Moreira, Nene and Marcio Bahia.
}

Lucas Gomes Maia Tome Pimentel

University of Louisville

Follow this and additional works at: https://ir.library.louisville.edu/etd

Part of the Music Education Commons, Musicology Commons, Music Performance Commons, and the Music Practice Commons

\section{Recommended Citation}

Gomes Maia Tome Pimentel, Lucas, "Brazilian rhythms on the drum set: stylizations of baiao, frevo and maracatu by drummers Airto Moreira, Nene and Marcio Bahia." (2019). Electronic Theses and Dissertations. Paper 3151.

https://doi.org/10.18297/etd/3151

This Master's Thesis is brought to you for free and open access by ThinkIR: The University of Louisville's Institutional Repository. It has been accepted for inclusion in Electronic Theses and Dissertations by an authorized administrator of ThinkIR: The University of Louisville's Institutional Repository. This title appears here courtesy of the author, who has retained all other copyrights. For more information, please contact thinkir@louisville.edu. 
BRAZILIAN RHYTHMS ON THE DRUM SET:

STYLIZATIONS OF BAIÃO, FREVO AND MARACATU BY DRUMMERS

AIRTO MOREIRA, NENÊ AND MÁRCIO BAHIA

By

Lucas Gomes Maia Tomé Pimentel

B.M., Universidade Federal de Goiás, 2015

A Thesis Submitted to the Faculty of the School of Music of the University of Louisville in Partial Fulfillment of the Requirements for the Degree of

Master of Music in Music, Jazz Performance

School of Music

University of Louisville

Louisville, Kentucky

May 2019 

BRAZILIAN RHYTHMS ON THE DRUM SET:

STYLIZATIONS OF BAIÃO, FREVO AND MARACATU BY DRUMMERS

AIRTO MOREIRA, NENÊ AND MÁRCIO BAHIA

By

Lucas Gomes Maia Tomé Pimentel

B.M., Universidade Federal de Goiás, 2015

A Thesis Approved on

April 30, 2019

by the following Thesis Committee:

Dr. Gabriel Evens

Professor Christopher Fitzgerald

Dr. Gregory Byrne 


\section{DEDICATION}

To my parents, Layne and Jacinto, to my brother, Saulo, and to my wife, Nathália.

Nada do que aprendi na escola valeria a pena se não houvesse aprendido com vocês o que é o amor 


\section{ACKNOWLEDGEMENTS}

I would like to acknowledge all the professors of the

Jazz Department of the University of Louisville.

Thank you for the support, inspiration, and friendship

Mike Hyman, Mike Tracy, Gabe Evens, Chris Fitzgerald, Ansyn Banks, Jerry Tolson and Craig Wagner. 


\section{ABSTRACT \\ BRAZILIAN RHYTHMS ON THE DRUM SET: \\ STYLIZATIONS OF BAIÃO, FREVO AND MARACATU BY DRUMMERS AIRTO \\ MOREIRA, NENÊ AND MÁRCIO BAHIA \\ Lucas Gomes Maia Tomé Pimentel}

April 30, 2019

The objective of this research is to gather and analyze stylizations of Brazilian folk rhythms baião, frevo and maracatu in contemporary Brazilian jazz. For this end, I examined transcriptions from well-known contemporary drummers Airto Moreira, Nenê and Márcio Bahia. Firstly, I reviewed the path of the drum set in Brazil by examining the important contributions made by drummers Luciano Perrone and Edison Machado. After that, I presented musical characteristics of baião, maracatu and frevo in their original environment, followed by analysis of each rhythm's stylizations to the drum set made by drummers Airto Moreira, Nenê and Márcio Bahia. I concluded that, to successfully transpose these Northeast Brazilian rhythms from percussion ensembles to the drum set, it is important to identify key patterns from the original source to be featured on the stylization, as well as to consider technical solutions that are already part of the drum set vocabulary. Tags: Brazilian jazz, drum set stylization, Airto Moreira 


\section{TABLE OF CONTENTS}

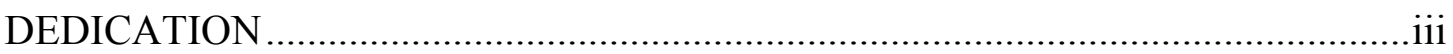

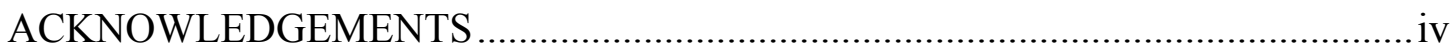

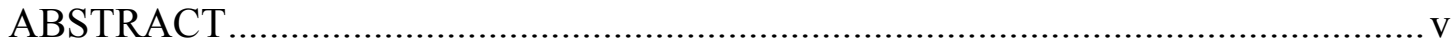

LIST OF FIGURES …...................................................................................

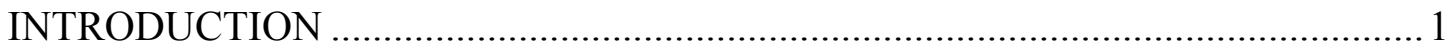

CHAPTER 1 - THE BRAZILIAN DRUMMER'S PERFORMANCE ........................ 4

1.1 - Music in Rio de Janeiro $(1900-1960)$........................................................... 4

1.2 - Interpreting percussion ensembles' rhythm on the drum set.......................... 7

1.3 - Luciano Perrone: father of Brazilian drum set ................................................. 8

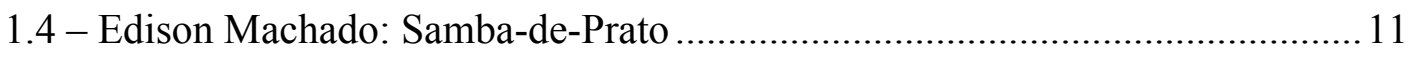

CHAPTER 2 - HERMETO'S DRUMMERS ......................................................... 14

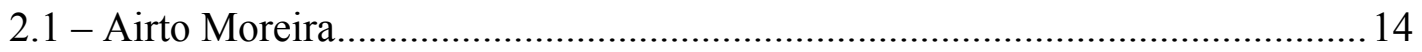

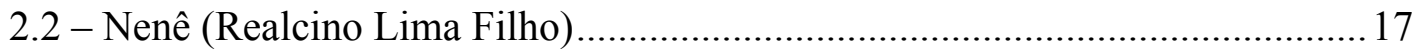

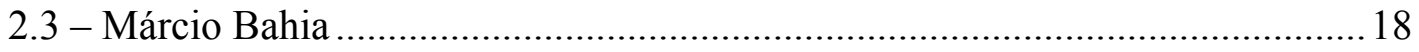

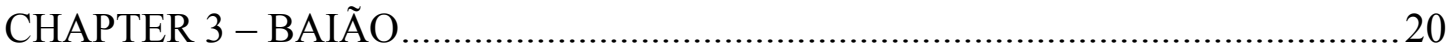

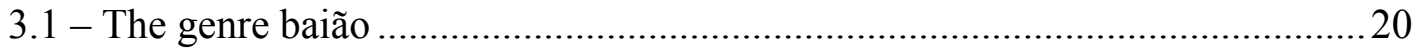

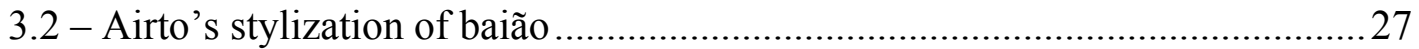

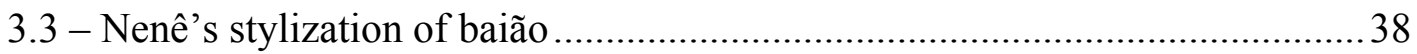

3.4 - Márcio Bahia’s stylization of baião ............................................................. 40

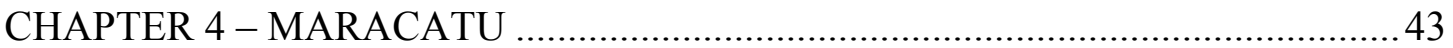

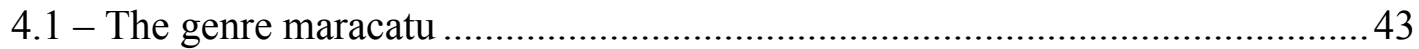

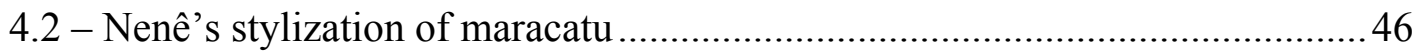

4.3 - Márcio Bahia’s stylization of maracatu .......................................................... 48

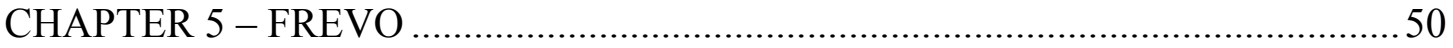

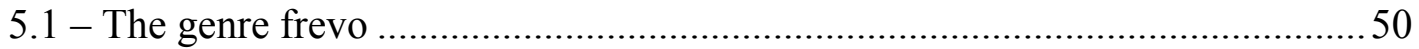

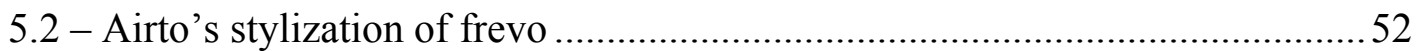

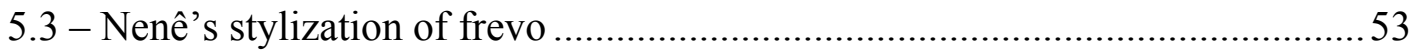

5.4 - Márcio Bahia's stylization of frevo .................................................................5 


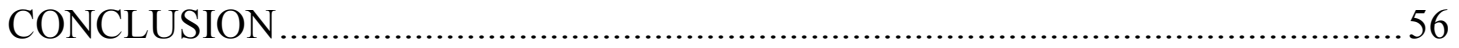

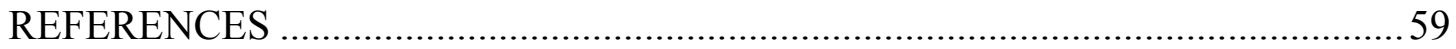

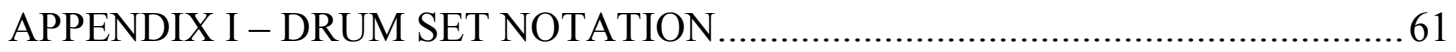

APPENDIX II - LIST OF MUSICAL EXAMPLES ...............................................62

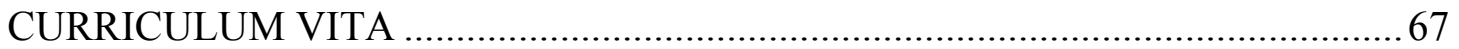




\section{LIST OF FIGURES}

FIGURE

PAGE

1. Perrone's samba-batucada............................................... 10

2. Measures 1-17 from the tune "Só Por Amor" ............................12

3. Excerpt from the tune "Quintessência"........................................................13

4. First formation of Gonzaga's trio.....................................22

5. Baião variations on the zabumba, triangle and woodblocks.................23

6. Xaxado variations on the zabumba and woodblock........................24

7. Xote variations on the zabumba and woodblock..........................25

8. Forró variations on the zabumba and woodblock........................25

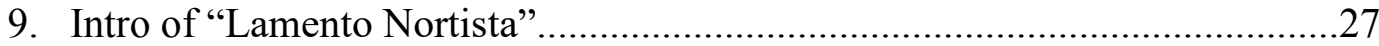

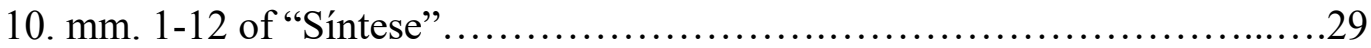

11. mm. 13-20 of "Síntese" .................................................29-30

12. mm. 21-30 of "Síntese" ....................................................

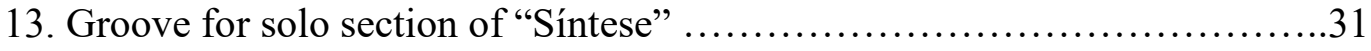

14. Teleco-teco pattern................................................... 31

15. Stylization of forró on tune "Vim de Sant'Ana".............................32

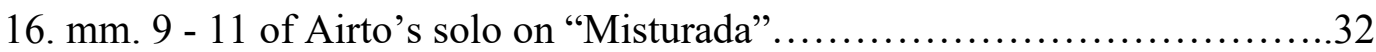

17. mm. 33 - 36 of Airto's solo on "Misturada".................................... 33

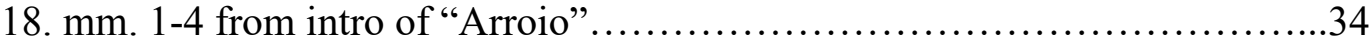

19. mm. 5-12 from intro of "Arroio" ................................... $34-35$

20. mm. 13-20 from intro of "Arroio"........................................

21. Drum set groove on alternate take of tune "Arroio"...........................37 
22. Variation of drum set groove on alternate take of tune "Arroio"

23. Drum set groove during interlude on alternate take of tune "Arroio" .37

24. Drum set groove during solos on alternate take of tune "Arroio".... .38

25. Nenê's stylizations of baião on the tune "Suite Norte, Sul, Leste, Oeste".....39

26. Nenê's stylizations of baião on the tune "Loro". .40

27. Márcio Bahia's stylizations of baião on "De sábado pra Dominguinhos" 41

28. Márcio Bahia's stylization of baião on tune "Baião Brasil" .41

29. Márcio Bahia's stylization of baião on tune "Vera Cruz" .42

30. Common variations of maracatu groove played by percussion ensemble.... 45

31. Nenê's stylization of maracatu on tune "Maracatu" .47

32. Example 1 of Nenê's stylization of maracatu from his method book .47

33. Example 2 of Nenê's stylization of maracatu from his method book. .47

34. Bahia's stylization of maracatu on tune "Quiabo". $48-49$

35. Fundamental frevo groove played by percussion ensemble. .52

36. Airto's stylization of frevo .53

37. Nenê's stylization of frevo.... .53

38. Variations of Nenê's stylization of frevo .54

39. Bahia's stylization of frevo.......................................54

40. Bahia's stylization of frevo........................................55

41. Variations of Bahia's stylization of frevo.............................55 


\section{INTRODUCTION}

The drum set was invented by the end of the $19^{\text {th }}$ century in the United States of America, and it was not long after that the drum set arrived in Brazil. During the early $20^{\text {th }}$ century, North American music was being introduced in Brazilian households through music recordings of the popular cakewalk, foxtrot and charleston dances. This music set the stage for the broad use of the drum set in Brazilian jazz bands, and also influenced the repertoire, which was composed of North American, European and Brazilian music. At this point, the percussionist had to perform the dance rhythms as maxixe, lundu, polkas and jongo on this new North American instrument. ${ }^{1}$ Consequently, the process of its incorporation into this new environment created a different path on which the Brazilian drummer's performance would evolve throughout the decades.

Ever since that time, there has remained a complex network of interaction encompassing Brazilian and North American music, its musicians, the drum set itself, and other musical elements. One example of this interaction is the specific way the invention and incorporation of the drum set had a massive impact on both jazz and Brazilian music. $^{2}$

\footnotetext{
${ }^{1}$ Leandro Barsalini, “As Sínteses de Edison Machado" (Master Thesis, Universidade de Campinas, 2009), 26.

${ }^{2}$ Brown, T. Dennis, 2003 "Drum set," Grove Music Online, accessed Sep. 19, 2018, http:///www.oxfordmusiconline.com/grovemusic/view/10.1093/gmo/9781561592630 $.001 .0001 /$ omo-9781561592630-e-2000130700
} 
Musical influence among drummers from these countries occurs both ways and is a product of cultural interaction. In this context, the Brazilian drummer is compelled to try new musical approaches on the drum set even with its limitations, ${ }^{3}$ as well as replicate the rhythms previously performed only by percussion ensembles.

The most popular Brazilian rhythm, the samba, preceded and ultimately spawned the commercially successful bossa-nova. Samba was recorded by many North American jazz musicians and was commonly featured in big band arrangements and in percussion method books. Although North American jazz has focused on only a few of the enormous variety of rhythmic styles in Brazilian folk music, other Brazilian rhythms, such as baião, maracatu and frevo, were also explored in the context of improvised music but remain obscure outside their native country. Moreover, Brazilian drummers use a vocabulary that includes many typical Brazilian rhythms stylized under influence of North American jazz drummers.

The objective of this thesis is to analyze the stylization of Brazilian folk rhythms baião, frevo and maracatu in contemporary Brazilian jazz. By illuminating the origins and musical characteristics of these lesser-known styles outside of Brazil, musicians throughout the world will have access to a wider variety of the rich rhythms of Brazilian music. The methodology consists of examining and analyzing transcriptions from well-known contemporary drummers Airto Moreira, Nenê and Márcio Bahia. These musicians make exceptional research subjects because of their

\footnotetext{
${ }^{3}$ The drum set is a dynamic instrument, which evolved from what was called a trap set, composed by many different percussion instruments (woodblocks, cowbells, chimes, tambourine) besides drums and cymbals. While the drummer can and does incorporate other instruments to the set, the core is composed of bass drum, hi-hats, ride cymbal, snare drum and toms and has been established as a standard drum set through the decades.
} 
contribution to and influence on the subsequent generations of Brazilian jazz drummers.

Although analyzing the stylization of samba is not the goal of this research, knowing some of its history is fundamental to understanding the North American influence over the evolution of drum set vocabulary regarding Brazilians rhythms. Thus, the first chapter covers the history of samba, its origins, and its dissemination throughout Brazil until the emergence of bossa-nova and samba-jazz. It also reviews the path of the drum set in Brazil by examining the important contributions made by drummers Luciano Perrone and Edison Machado, since both were responsible for key innovations regarding the Brazilian drum set vocabulary. Perrone was responsible for the dissemination of the hegemonic approach of playing samba on the drum set until the 1950s, which is known as samba-batucada. Edison Machado influenced his generation and the generations after him because of the development of the samba-deprato, featured in the styles of bossa-nova and samba-jazz. ${ }^{4}$

\footnotetext{
${ }^{4}$ Leandro Barsalini, "As Sínteses de Edison Machado" (Master Thesis, Universidade de Campinas, 2009), 3.
} 


\section{CHAPTER 1 - THE BRAZILIAN DRUMMER'S PERFORMANCE}

\section{1 - Music in Rio de Janeiro (1900 - 1960)}

By the end of the $19^{\text {th }}$ century, the music cultivated by the aristocracy of Rio de Janeiro was largely influenced by European culture. French and English dances would be performed on the piano during social occasions. On the other hand, the majority of the population was composed of urban workers and recently freed slaves who migrated from the rural part of the state and also from Bahia. These AfroBrazilians brought percussive music from their religious tradition candomblé. These musical worlds would sometimes be linked by the work of pianists like Ernesto Nazareth (1863 - 1934) and Chiquinha Gonzaga (1847 - 1935), who would use AfroBrazilian rhythms in their compositions. Both were pioneer figures in the process of the creation of the choro as a musical genre, which blends European and AfroBrazilian cultures to become one of the first genuine Brazilian urban genres. ${ }^{5}$ Therefore, syncopated dances as the maxixe, lundu, and tango would be featured in some pianists' repertoire, side by side with European polkas and schottisches. ${ }^{6}$ Another important figure in Brazilian popular music from this period is Pixinguinha (1897 - 1973), who performed choros, sambas and maxixes with his successful group Oito Batutas in Rio de Janeiro and abroad during the 1920s.

${ }^{5}$ Leandro Barsalini, “As Sínteses de Edison Machado” (Master Thesis, Universidade de Campinas, 2009), 14-15.

${ }^{6}$ Ibid., 15. 
At this time, Rio de Janeiro was the capital of the country and the most representative city in the Brazilian cultural scene, given its richness regarding the Afro-Brazilian music, dance and religion, as well as the European influence over the aristocracy. ${ }^{7}$ In the late 1920 s, samba still was a marginal music genre performed in a few poor and Afro-Brazilian neighborhoods of Rio de Janeiro. In the 1930s, radio stations and record labels located in Rio were responsible for spreading the music made in the city throughout the country, and as a result, in the next decade, samba was a widely recognized symbol of Brazilian national identity. ${ }^{8}$

Since its ascension as the most recorded and broadcasted music genre among popular culture in Brazil, the samba has kept its status as a symbol of national identity until today. Moreover, it had been explored regarding its musical and political aspects, transforming itself in to a wide source of inspiration to artistic expression. ${ }^{9}$ The internationally famous Brazilian musical movement known as bossa-nova is an important example of a cultural product drawn from samba, but it is not the only one. Since it emerged, the word samba had frequently been accompanied by a suffix which would determine a subgenre, such as: samba-canção, samba-exaltação, samba-demorro, samba-urbano, samba-de-terreiro, samba-de-breque, samba-batucada, sambachoro, samba-maxixe, samba-de-gafieira. These terms relate to cultural products forged before the 1950s, and each samba subgenre would be distinguished by different aspects regarding the cultural product. For instance, it could be related to the

7 Leandro Barsalini, “As Sínteses de Edison Machado" (Master Thesis, Universidade de Campinas, 2009), 13.

${ }^{8}$ Bryan McCann, Hello, Hello Brazil: Popular Music in the Making of Modern Brazil (Durham: Duke University Press, 2004), 41.

${ }^{9}$ Ibid., 42. 
lyric content, the instrumentation, the environment where it was performed, in addition to its musical characteristic.

A myriad of other subgenres would follow; among them, the samba-jazz represents an important point of transition regarding the Brazilian drummer's performance. Beyond that, it is important to picture the environment where the samba-jazz emerged, in order to clarify what musical aspects converged to create the style.

Like the bossa-nova, samba-jazz is a specific result from a fusion of jazz harmonies and samba rhythm, both emerging around the late 1950s and early 1960s in Rio de Janeiro. In this case, there are some differences between these styles that allow both to coexist and be distinguished from each other, although this line can be blurry.

The researcher J. M. Saraiva found that the word samba-jazz was not frequently used among the music community or the press by the time the music itself was happening. It has been recently reinforced after music labels promoted the rebirth of recordings from that specific period of time in Rio. ${ }^{10}$ Finally, the term samba-jazz ended up combining aesthetic related music under the same category. ${ }^{11}$ When trying to accomplish the complex task of delineating the samba-jazz as a musical style, Saraiva also indicates that, among musicians, listeners and musicologists, samba-jazz is commonly indicated as a subgenre of bossa-nova, since both styles were practiced during the same period of time. However, for some musicians and musicologists, the samba-jazz can be realized as the ancestor of the bossa-nova. ${ }^{12}$

${ }^{10}$ Joana Martins Saraiva, “A Invenção do Samba-jazz: Discursos sobre a Cena Musical de Copacabana no Final dos Anos 1950 e Início dos Anos 1960” (Master Thesis, PUC-Rio, 2007), 16-17.

${ }^{11}$ Ibid., 18.

12 Ibid., 19. 
The main aspects that sets samba-jazz apart are: the instrumentation, the improvisation, the musical interaction within the band and its specific audience. These contrasting characteristics in relation to the bossa-nova, made it possible to the samba-jazz emerge as a fresh product resulting from the fusion of jazz and samba.

Finally, an important turn happened in the Brazilian musical scene within the advent of samba-jazz. Because this music was performed by small groups and influenced by bebop musicians, it helped change the way instrumental music was appreciated. ${ }^{13}$ Similar to the transition from swing to the bebop era in United States, the samba-jazz represented a new way to listen to instrumental music, being forged and performed with no intent to make people dance. ${ }^{14}$ Some of the prominent groups recorded in this era are Tamba Trio, Zimbo Trio, Sambalanço Trio, Bossa Três and Rio 65 Trio. One of the characteristics in common between these records is the piano trio as a core of the style.

\section{2 - Interpreting percussion ensembles' rhythm on the drum set}

One of the aspects that made the transition to the drum set by the Brazilian culture possible, was the familiarity the musicians already had with the pieces which constitute the kit. The snare drum, bass drum and cymbals were not only present in military bands, but were also similar to some of the percussion instrument from samba and other folk percussion ensembles from Brazil. ${ }^{15}$ For instance, the snare drum sounds like the tarol, and the bass drum and tom-toms resemble the surdos and

${ }^{13}$ Késia Decoté Rodrigues, "Música Popular Instrumental Brasileira (1970-2005): Uma Abordagem Subsidiada pelo Estudo da Vida e Obra de Oito Pianistas" (Master Thesis, Universidade Federal do Rio de Janeiro, 2006), 9-10.

${ }^{14}$ Ibid., 10.

${ }^{15}$ Leandro Barsalini, “As Sínteses de Edison Machado" (Master Thesis, Universidade de Campinas, 2009), 12. 
alfaias. All of these instruments are typical of samba and maracatu. Thus, the drum set itself represented a set of largely familiar sounds that could be performed by one percussionist all at the same time. The real challenge was given to the drummer, who needed to figure out how to combine the voices together, developing skills of coordination and orchestration, minding dynamics and timbre possibilities of each piece within the drum set.

The process of interpreting styles from percussion ensembles on the drum set can involve different challenges depending on the style. Over the decades, many drummers have tried different approaches of performing Brazilian rhythms.

Prior to examining the stylization of the rhythms baião, maracatu and frevo, it is necessary to delineate how the instrument's language evolved in Brazilian music. I will review the important accomplishments made by the drummers Luciano Perrone and Edison Machado, as well as briefly describe their pioneering approach when interpreting samba on the drum set.

\section{3 - Luciano Perrone: father of Brazilian drum set}

The drum set arrived in Brazil during the second decade of the $20^{\text {th }}$ century, and the name of Luciano Perrone (1908-2001) emerges above all, among the first generation of musicians to play the instrument. Perrone started his career as a percussionist in ensembles providing music for silent film exhibitions. He started playing with samba singers, orchestras and jazz bands when he was 16 old. In 1929, he was already one of the most requested drummers of Rio de Janeiro where he was 
performing with different ensembles and recording for various labels such as Columbia, RCA and Victor. ${ }^{16}$

Luciano Perrone is an important figure in the history of the drum set in Brazil because he made this instrument present in Brazilian music during his long career performing in radio orchestras. He worked alongside the composer and arranger Radamés Gnattali for 59 years in radio stations, including the Radio Nacional orchestra. In 1939, the song “Aquarela do Brasil," composed by Ary Barroso, was arranged by Gnattali for jazz orchestra, and featured samba syncopations in the horn section. Luciano Perrone, as the lead drummer of the orchestra, was the one who recommended shifting some of the percussion rhythmic patterns to the horns in order to fulfill some space in the arrangement, since on the occasion of this recording he was the only percussionist available. This recording is a landmark of Brazilian music, because it changed the sound of samba on the radio, consequently changing the sound of samba in general. ${ }^{17}$ He also developed a Brazilian approach to playing the drum set, synthesizing rhythmic layers from percussion ensembles on the instrument. ${ }^{18}$ His stylization of samba rhythms on the drum set emphasized the use of the drums, frequently giving up the use of cymbals. This approach of playing samba on the drum set is called samba-batucada, and it centers the patterns on the snare drum and bass drum, sometimes using the cymbals only to underline the ending of two-bar phrases (Figure 1). ${ }^{19}$

${ }^{16}$ Leandro Barsalini, “As Sínteses de Edison Machado" (Master Thesis, Universidade de Campinas, 2009), 29.

${ }^{17}$ Bryan McCann, Hello, Hello Brazil: Popular Music in the Making of Modern Brazil (Durham: Duke University Press, 2004), 71-72.

${ }^{18}$ Leandro Barsalini, "As Sínteses de Edison Machado" (Master Thesis, Universidade de Campinas, 2009), 30.

${ }^{19}$ Ibid., 3 . 

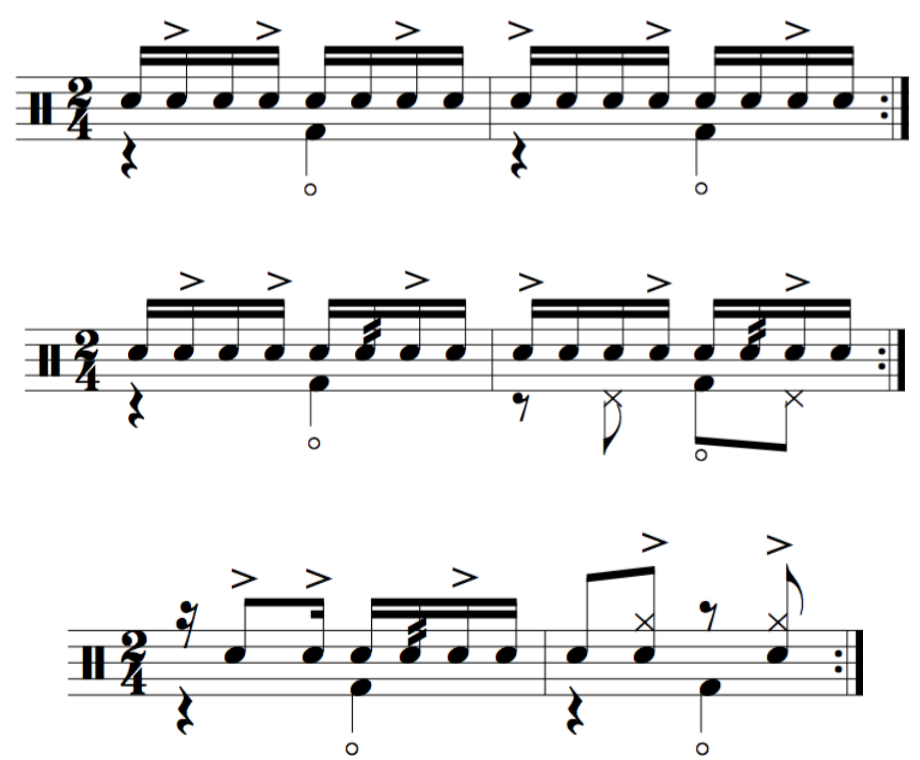

Figure 1 - Perrone's samba-batucada (transcribed from Bolão, p.137)

Luciano Perrone once said: "I have never worried about imitating Gene Krupa, because I was interested in the batuque of samba". ${ }^{20}$ This statement clarifies the music Perrone was drawing his influences from when playing the drum set. The batuque of samba, also known as samba-batucada, refers to the music made by percussion ensembles in Rio de Janeiro, representing a challenging stylization to the musician who aims to perform it on the drum set.

By this point, the drum set had already had its vocabulary being developed along Brazilian rhythms in dialogue with African rooted percussion instruments. Moreover, its specific capacity of compressing layers of rhythms and textures, added to the North American influence on Brazilian culture, made it the first choice of percussion instruments to be in a Brazilian jazz band, a radio orchestra and a gafieira

${ }^{20}$ Oscar Bolão, Batuque is a Privilege, Percussion in the Music of Rio de Janeiro (São Paulo: Lumiar Press, 2009), 36. 
band. ${ }^{21}$ In this sense, drummers were specialized percussionists, usually capable of playing other percussion instruments, while maintaining a consolidated and specific niche in the music business.

\section{4 - Edison Machado: Samba-de-Prato}

Edison Machado (1943-1990) was born in Rio de Janeiro. He was a selftaught musician who learned how to play the drum set by watching and listening to radio orchestra's drummers, such as Luciano Perrone and Edgar Nunes Rocca. He was also an admirer of North American drummers he would listen to on radio during his teenage years, such as Max Roach and Art Blakey. ${ }^{22}$

Edison is known by his extended career going from playing in clubs in Rio de Janeiro with world famous Brazilian composer Sergio Mendes, to recording alongside North American jazz musicians such as Ron Carter and Chet Baker. He also recorded the emblematic bossa-nova album Antonio Carlos Jobim - The composer of Desafinado plays (1963). He recorded as a sideman, but also as a bandleader, featuring arrangements by Moacir Santos and Raul de Souza on his albums. ${ }^{23}$

The legacy he left for drummers is his stylization of samba when performing along his group, Rio 65 Trio. In this context, Edison is spotlighted showcasing a more interactive way to keep the rhythmic flow. Strongly influenced by bebop drummers, he would perform variations of ostinatos on the ride cymbal, hi-hats and bass drum, while using the left hand to establish a dialogue with the piano and bass players. This

${ }^{21}$ Leandro Barsalini, "Modos de Execução do Samba na Bateria" (PhD Diss., Universidade de Campinas, 2014), 88.

${ }^{22}$ Ibid., 76-77.

${ }^{23}$ Ibid., 93. 
way of conducting the band is known as samba-de-prato, and is one of the key aspects of samba-jazz.

In the tune "Só Por Amor," there are some examples of characteristics of Edison Machado's approach when playing the samba-jazz (Figure 2). He centers the time flow around the bass drum, hi-hat and ride cymbal. The ostinato played using the bass drum presents a fixed pattern, known as bumbo-à-dois. While the left foot plays the hi-hat on upbeats, the right-hand plays sixteenth-notes continually on the ride cymbal, and the left hand is free to explore colors on the snare drum and toms, featuring patterns and rhythmic cells commonly played on tamborins, surdos and other percussion instruments from folk samba ensembles.

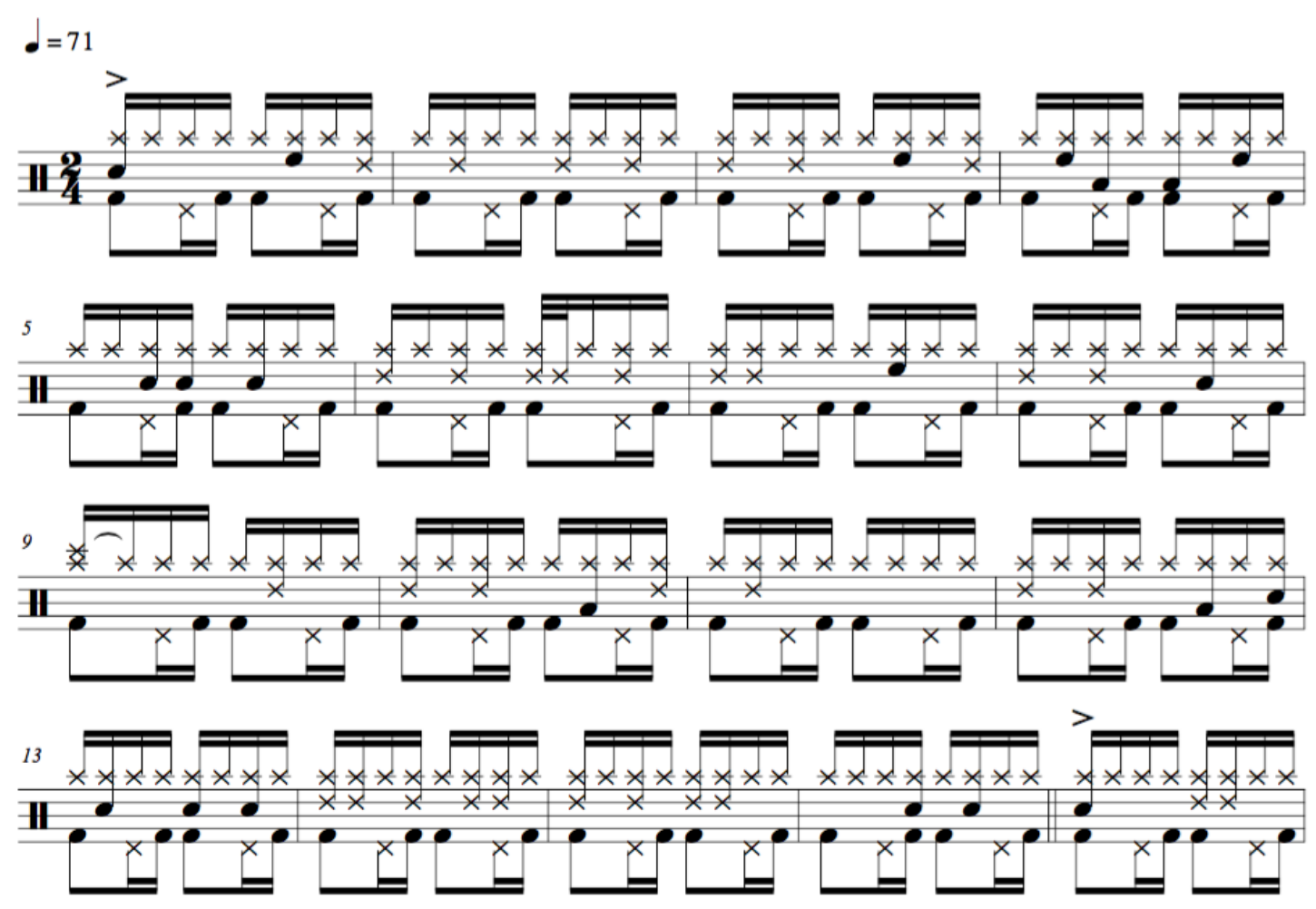

Figure 2 - Measures 1-17 from the tune "Só Por Amor" (Edison Machado é Samba Novo, 1964)

At faster tempos, Edison would play less notes on the ride cymbal, performing ostinatos based on syncopated rhythmic cells characteristic of the tamborim. This technique allows more space for other instruments to interact, at the 
same time giving the drummer the opportunity to use the ride cymbal as an interactive layer (Figure 3).

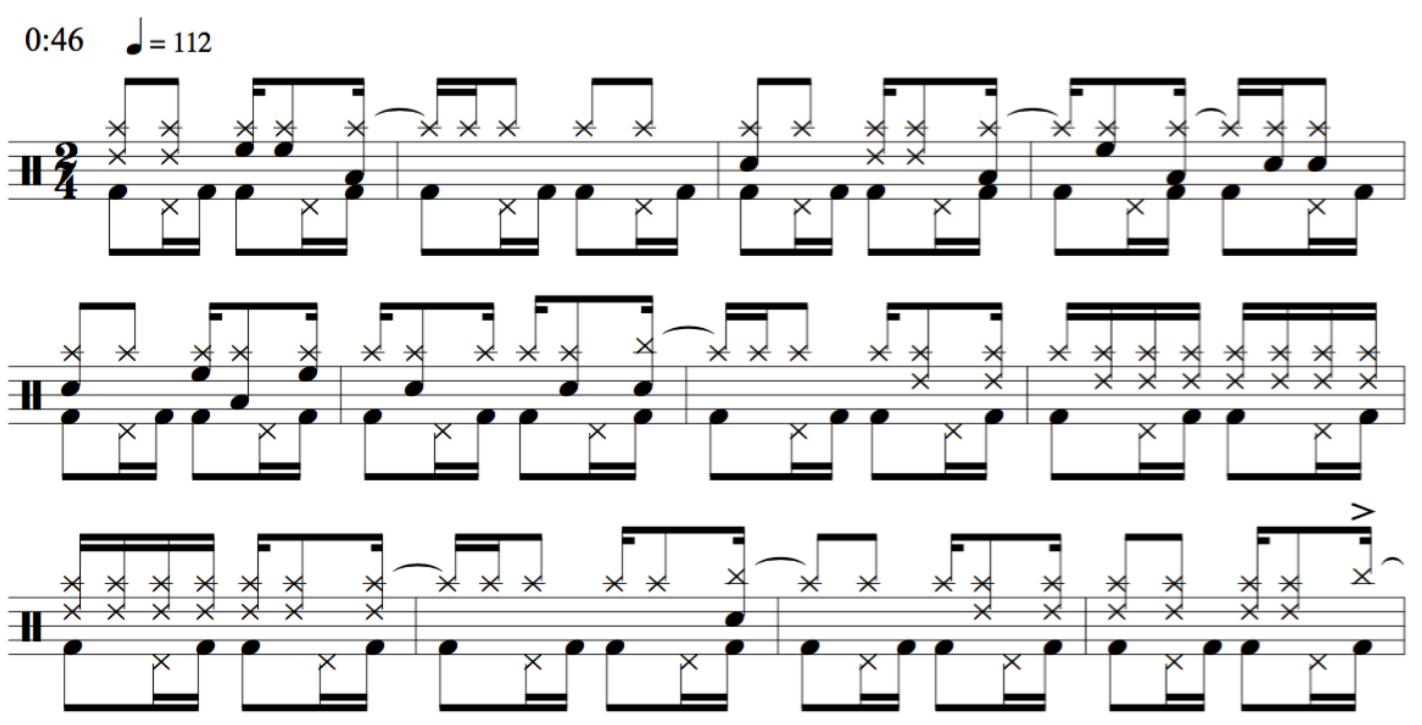

Figure 3 - Excerpt from the tune "Quintessência” (Edison Machado é Samba Novo, 1964) 


\section{CHAPTER 2 - HERMETO'S DRUMMERS}

Samba-jazz inspired drummers to be more musically interactive and to stylize other Brazilian rhythms on the drum set, opening their ears to new textures on the instrument. The composer and multi-instrumentalist Hermeto Pascoal, also made important contributions to drummers to find new ways of stylization of folk rhythms on the drum set. In the groups Sambrasa Trio and Quarteto Novo, he exposed the drummers Airto Moreira and Nenê to the music from Northeast Brazil, encouraging them to stylize rhythms as the baião and frevo. ${ }^{24}$

Later, in 1981, Hermeto invited the drummer Márcio Bahia to be part of his group, which still performs around the world. This group rehearsed 6 hours every day for 12 years, between 1981 and 1993. From this experience, Márcio said in interview, he learned what he knows about Brazilian rhythms as the xaxado, maracatu, samba, baião, xote, frevo, ijexá and maxixe..$^{25}$

\section{1 - Airto Moreira}

Regarding the stylization of rhythms from the Brazilian Northeast on the drum set, Airto Moreira had an important role, being responsible for merging rhythms as the baião to the jazz and samba-jazz aesthetics. ${ }^{26}$

\footnotetext{
${ }^{24}$ Guilherme Marques Dias, "Airto Moreira: do Samba-jazz à Música dos Anos 70" (Master Thesis, Universidade de Campinas, 2013), 106.

${ }^{25}$ Fabio Bergamini, "Márcio Bahia e a 'Escola do Jabour"” (Master Thesis, Universidade de Campinas, 2014), 26.

${ }^{26}$ Guilherme Marques Dias, "Airto Moreira: do Samba-jazz à Música dos Anos 70" (Master Thesis, Universidade de Campinas, 2013), 88.
} 
Airto Moreira, was born in Itaiópolis in 1941 and moved to Curitiba in 1955, where he started his professional musician career as a singer, percussionist and drummer. In 1960, he moved to São Paulo and started performing in night clubs as a drummer, and first achieved national recognition through his drumming in the recordings of the Sambalanço Trio, alongside the pianist Cezar Camargo Mariano and bass and harmonica player Humberto Clayber. Within this group Airto developed his samba-jazz vocabulary and recorded four albums: Sambalanço Trio (1964); Improviso Negro (1965); Reencontro com Sambalanço Trio (1965); Lennie Dale \& Sambalanço Trio (1965). He also was recorded playing samba-jazz as a sideman in the album by trombonist Raul de Souza À Vontade Mesmo (1965). ${ }^{27}$ Airto's performance as a drummer in these recordings is largely influenced by Edison Machado's stylization of samba, being interactive within the band while having the ride cymbal as a core piece of the drum set to play samba patterns.

In 1965, the trio changed the name to Sambrasa Trio, as Cezar Camargo Mariano left the group and Hermeto Pascoal took his position as pianist. This new formation brought even more space for Airto to be interactive, as well as exposing him to Northeast rhythms such as the xaxado. In this formation, they recorded the album Som Maior (1965), on which Airto is featured on drum solos on nine out of eleven tracks.

In 1966, the composer and singer Geraldo Vandré asked Airto to gather musicians to go on tour around the country with him. At that time, Airto was part of the group Trio Novo, and invited Hermeto Pascoal to join the trio to tour as Vandré's

${ }^{27}$ Guilherme Marques Dias, "Airto Moreira: do Samba-jazz à Música dos Anos 70" (Master Thesis, Universidade de Campinas, 2013), 17. 
band member. This new formation was named Quarteto Novo, composed by Théo de Barros (acoustic bass and acoustic guitar), Heraldo do Monte (electric guitar and viola caipira), Airto (drum set and percussion) and Hermeto Pascoal (piano and flute). ${ }^{28}$

The group recorded only the homonymous album Quarteto Novo (1967) before Airto moved to the USA. However, this band was the most important artistic project of Airto's career. On his album, he played more percussion than drum set, and often blended both. During the recording sessions, he had on the side of the drum set, two different pandeiros, caxixi, woodblocks and one triangle. There was no overdub in this situation, and it is possible to hear in the recording Airto transitioning from the drum set to the folk percussion instruments. He played only on the drum set on the tunes "Síntese," "Misturada" and "Vim de Sant'Ana".

In 1968, he moved to the USA, where he conquered his space in the jazz scene mostly because of his ability to play percussion in that context. He lived for almost two years in Los Angeles, then moved to New York, where his American career grew. In the Big Apple, he was living in the bassist Walter Brooks' apartment, where he had the opportunity to meet and play alongside Cannoball Adderley, Thelonious Monk and Joe Zawinul. In 1969, Airto met Miles Davis and joined his band playing percussion in the recording session of the iconic album Bitches Brew $(1970) .^{29}$

After having his name linked to Miles Davis, Airto had the opportunity to record solo albums. He recorded Natural Feelings (1970), and Seeds on the Ground (1971) launched by the label Buddah Records. On these albums, Airto started using

${ }^{28}$ Guilherme Marques Dias, "Airto Moreira: do Samba-jazz à Música dos Anos 70" (Master Thesis, Universidade de Campinas, 2013), 26.

${ }^{29}$ Ibid., 38. 
overdubs to build layers of folk percussion instruments plus the drum set. Still in 1971, he was recorded as a percussionist on the first album of (the) iconic group Weather Report. During the following two years, he recorded two important albums as a member of Chick Corea's group Return to Forever, as well as two more albums as a leader: Free (1972); Fingers (1973). Airto's discography is extensive, and he had recorded over forty albums as a sideman or as a leader. ${ }^{30}$

\section{2 - Nenê (Realcino Lima Filho)}

Realcino Lima Filho, known by his nickname Nenê, was born in 1947, and learned how to play the pandeiro and the accordion during his childhood, mostly by watching professional musicians performing in his hometown. When he was 19 years old, he was already working as an accordionist, and decided to move to São Paulo, looking for better opportunities in the music market. After watching Airto Moreira playing alongside Hermeto Pascoal in the group Quarteto Novo, Nenê decided to study the drummer's approach on the instrument. When Airto moved to the USA, Nenê filled his place in the quartet and performed alongside Hermeto for several years in other ensembles, having the opportunity to record the albums A Música livre de Hermeto Paschoal (1973), Zabumbê-Bum-Á (1979) and Live in Montreux (1979).

Nenê also performed alongside other Brazilian artists of international renown, such as Egberto Gismonti, Milton Nascimento, Elis Regina, Gal Costa, Caetano Veloso and Gilberto Gil.

Nenê lived for 12 years in France, where he recorded the album Bugre in 1983, his first as a leader. After that, as a prolific composer, he released 13 more

${ }^{30}$ Guilherme Marques Dias, “Airto Moreira: do Samba-jazz à Música dos Anos 70” (Master Thesis, Universidade de Campinas, 2013), 40. 
albums under his name, featuring a strong improvisational character and only original compositions. Since 2001, the drummer has been performing alongside his trio around the world. Last year, Nenê released his two most recent albums: Verão (2018), featuring his trio, and Pantanal (2018), featuring new compositions arranged for quintet.

Regarding the stylization of Brazilian folk rhythms to the drum set, Nenê is part of the same generation of drummers as Airto Moreira, aware of the innovations brought to the Brazilian drummer's palette through the assimilation of jazz and Northeast Brazilian rhythms. In addition to Airto's interactive approach, he drew the Brazilian percussive vocabulary in his own way, always putting his own twist to the stylizations. Nenê also learned how to blend folk percussion to the drum set. However, he represents a very distinctive voice on the instrument mainly by exploring color possibilities and phrasing contours within the limitations of the drum set. ${ }^{31}$

\section{3 - Márcio Bahia}

Márcio Bahia was born in 1958 at Niterói, city in the state of Rio de Janeiro, Brazil. He started playing drums in 1973, in rock bands. He points out the bands Led Zeppelin, Black Sabbath and the guitar player Jimi Hendrix as his first influences. He learned about Brazilian drummers from the samba-jazz and North American drummers from the jazz scene in 1974, when he took his first drum lessons.

Some of the drummers that influenced Bahia are of Robertinho Silva, Nenê, Paulinho Braga, Airto Moreira, Milton Banana, Hélcio Milito and Luciano Perrone, as

${ }^{31}$ Guilherme Marques Dias, "Airto Moreira: do Samba-jazz à Música dos Anos 70" (Master Thesis, Universidade de Campinas, 2013), 106. 
well as the North American jazz drummers Tony Williams, Elvin Jones, Art Blakey, Buddy Rich and Joe Morello.

In 1977, he enrolled himself in a percussion course offered by Escola de Música Villa Lobos. Bahia studied for four years in this school, becoming a strong music reader while performing in symphonic orchestras and percussion groups as well. At some point, he left the orchestra to dedicate his time to the drum set. One day he was invited to go to a jam session with the Hermeto's group, and after that he became a member of that band. From 1981 to 1993, the group rehearsed 6 hours every day, and this was the period Bahia learned everything he knows about Northeast Brazilian rhythms as the xaxado, baião, xote, maracatu and frevo. 


\section{CHAPTER 3 - BAIÃO}

\section{1 - The genre baião}

In 1946, the musicians Luiz Gonzaga and Humberto Teixeira composed and recorded the song "Baião" in Rio de Janeiro. The moment the song was released, the music genre named after it was created as well. The lyrics of the song literally invite the listener to meet the new genre and to learn how to dance to it. Luiz Gonzaga, known as the King of Baião, also recorded other songs in the same style, being extremely successful during the next decade. However, the emergence of other musical movements as the bossa-nova and the tropicalism obfuscated the genre, which eventually made a comeback in the 1960s through compositions by younger musicians. ${ }^{32}$

Although the music and career of Luiz Gonzaga were forged at the Brazilian capital of that time, his creation is known as an important representation of the culture from the Northeast of Brazil. Gonzaga was born in Pernambuco and raised in a rural area in the state of Ceará, where he had rich cultural experience until he was 17 years old. It was after moving to Rio that he really learned how to play the accordion and had contact to the music made in the urban centers.

The word baião is both the name of a musical genre and of a rhythm. The rhythm is a subset of variety of rhythms featured in the repertoire of traditional dance

\footnotetext{
${ }^{32}$ Marcio Mattos Aragão Madeira, “A Contribuição da Música Tradicional do Cariri Cearence à Música Popular Brasileira por meio do Baião de Luiz Gonzaga" (PhD Diss., Universidad Complutense de Madrid, 2016), 53.
} 
parties from the Northeast of Brazil. These dance parties present merged characteristics from African, European and pre-colonial cultures, being known by many different names such as forró, baião and quadrilha. The musicians performing at these parties would sing and make use of different possibilities of instrumentation, including the accordion, percussion instruments similar to shakers, triangles and drums of different sizes, as well as flutes, plucked and bowed string instruments. ${ }^{33}$

Gonzaga performed the music genre baião as a blend of urban music from Rio de Janeiro and the music connected to his roots, since he achieved fame by composing and recording songs inspired by folk songs from his homeland. He made popular the trio instrumentation composed of accordion, triangle and the zabumba, by touring extensively inside the country with his group, of which he was the lead singer and accordionist. The picture below is from 1949 and displays the first formation of Gonzaga's trio, featuring him with his accordion, Catamilho with the zabumba and Zequinha as the triangle player (Figure 4). ${ }^{34}$ Besides this formation being popular in the context of baião, it was usual to have other instruments featured on baião live performances and recordings by Luiz Gonzaga. Acoustic guitar, pandeiro and agogos or woodblocks would be added to the core instrumentation consisting of zabumba, triangle and accordion.

The zabumba is similar to a bass drum. The top head is played by using a soft mallet to extract open or a muffled low sound. On the bottom head, the zabumba player

\footnotetext{
${ }^{33}$ Marcio Mattos Aragão Madeira, “A Contribuição da Música Tradicional do Cariri Cearence à Música Popular Brasileira por meio do Baião de Luiz Gonzaga” (PhD Diss., Universidad Complutense de Madrid, 2016), 66.

${ }^{34}$ Ibid., 283.
} 
uses a thin stick named bacalhau to pull a higher-pitched sound. These three different sounds combined with the triangle pattern, set up the compelling baião groove ${ }^{35}$ while the accordion provides harmonic and melodic accompaniment to the lead singer and backing vocals.

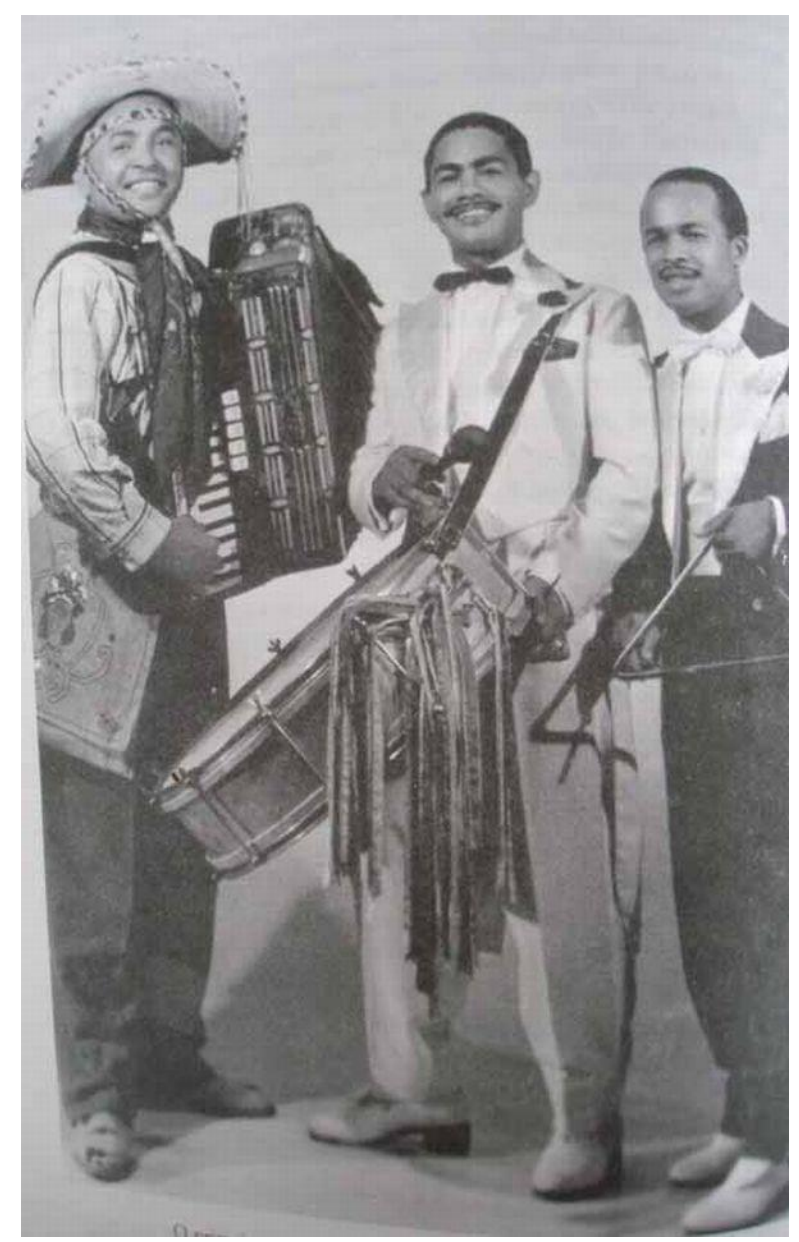

Figure 4 - First formation of Gonzaga's trio

35 The term "groove" is often used by musicians to qualify the rhythmic feel of a performance or to relate to specific rhythmic or melodic ostinatos played on a rhythmic section instrument. In this research, the word "groove" refers to layered patterns performed within the drum set or combined between more than one instrument. 
Woodblock $11 \frac{2}{4}$ y
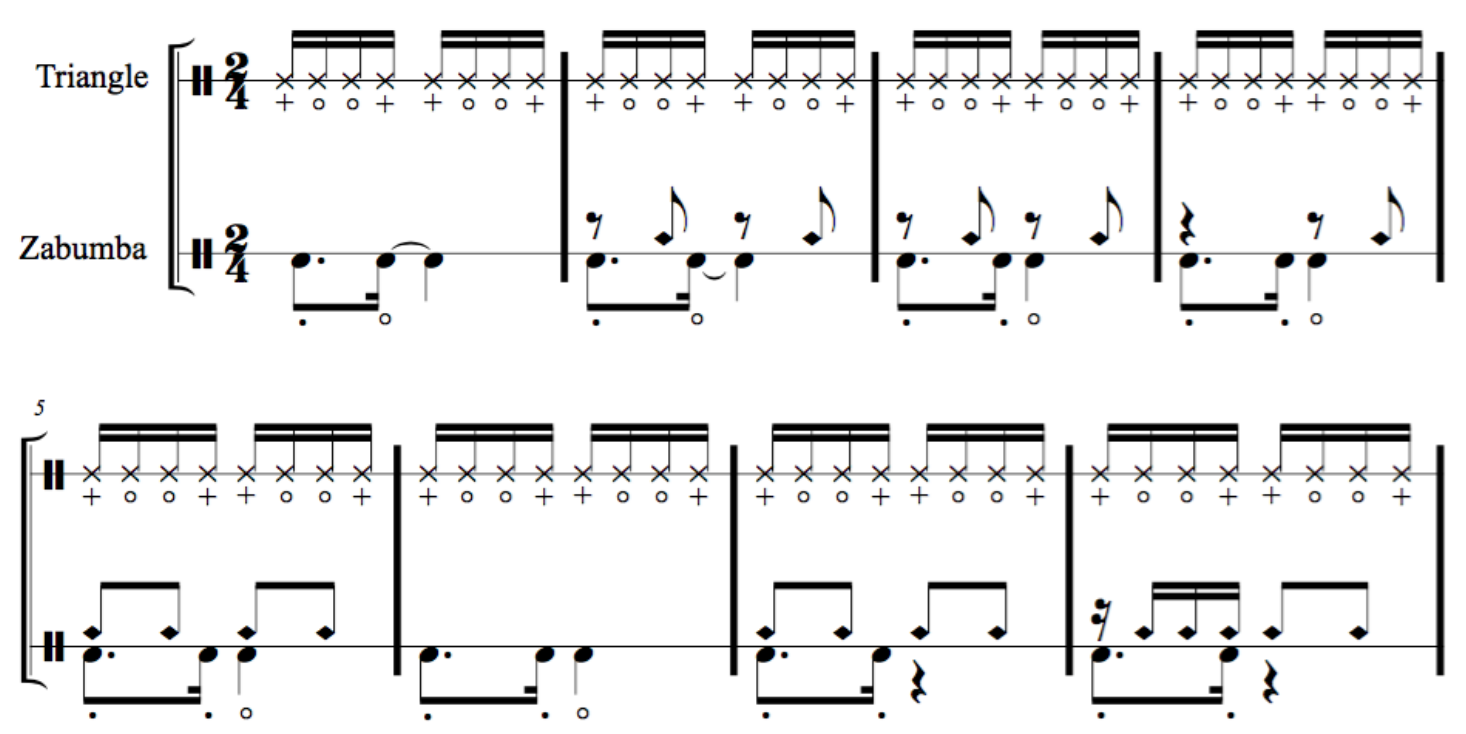

Figure 5 - Baião variations on the zabumba, triangle and woodblocks

In this context, Gonzaga and his trio performed not only the rhythm baião (Figure 5), but also a variety of rhythms that the homonymous music genre assembles, such as the xote, xaxado, forró, toada, arrasta-pé and marcha. These rhythms can present subtle differences from each other, and are frequently distinguished by the tempo they are played, or by variations in the zabumba and woodblock patterns. To name some of the most explored by drummers in the context of instrumental music: the baião, the xote, the xaxado and the forró.

The xaxado is the rhythm played as a beat to the homonymous dance (Figure 6). It is usually played in medium to fast tempos, and the dance is characterized as a male dance. The songs "Xaxado," and "Olha a Pisada," were recorded by Luiz Gonzaga and feature the rhythm as the lyrics describe the dance and folk tales behind its history. In addition to being a male dance, it represents virility, since it is 
connected to the figure of Lampião, the famous bandit leader in activity in Northeast Brazil between the 1920s and 1930s. Also, the zabumba player usually takes advantage of the particular syncopations of xaxado's variations to perform fills, having the xaxado as the rhythm of choice to perform solos. ${ }^{36}$
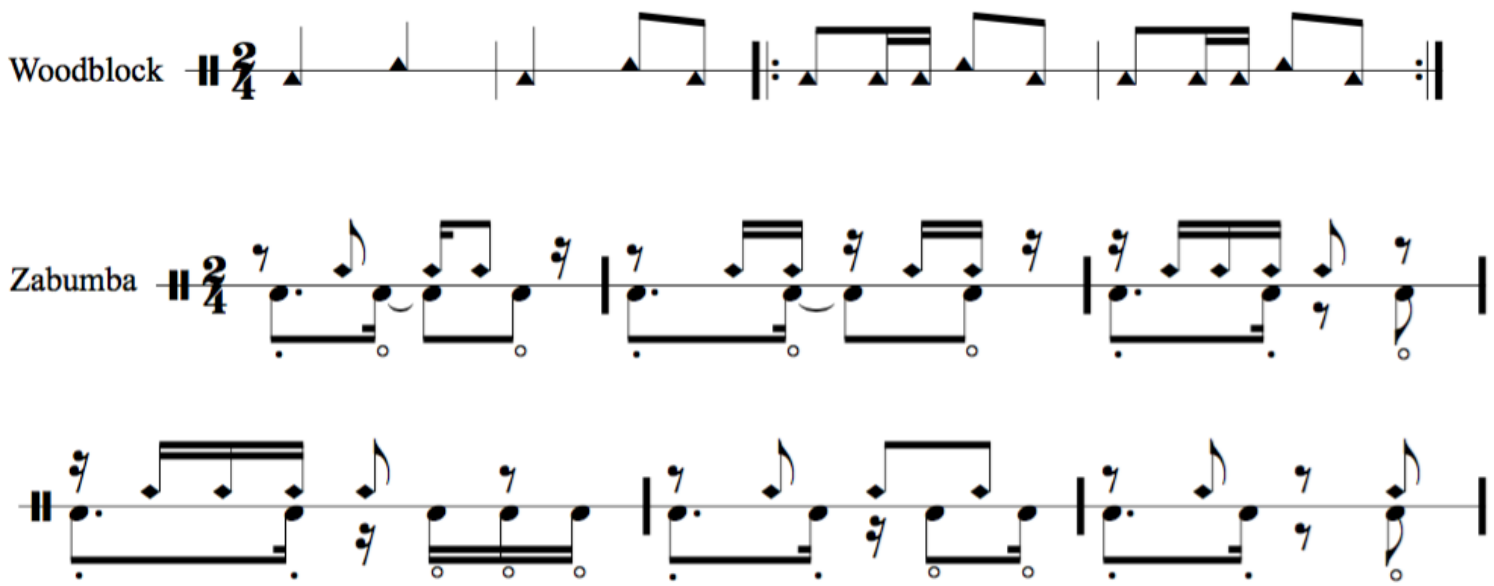

Figure 6- Xaxado variations on the zabumba and woodblock

The xote is a Brazilian variation of a rhythm imported from Europe, related to the German dance schottische, which arrived in Brazil around 1850 and became popular among choro players. Eventually, the foreign dance had its name transformed to xótis, as people in Brazil would try to pronounce the European word. The music and dance were transformed in Brazilian lands, and became the preferred rhythm to dance as a couple in the Northeast parties named forró. The xote is performed on slow to medium tempos, and it is also characterized by the open low sound of the zabumba played in the two eighth-notes on the second beat (Figure 7). ${ }^{37}$

\footnotetext{
${ }^{36}$ Marcio Mattos Aragão Madeira, “A Contribuição da Música Tradicional do Cariri Cearence à Música Popular Brasileira por meio do Baião de Luiz Gonzaga” (PhD Diss., Universidad Complutense de Madrid, 2016), 211.

${ }^{37}$ Ibid., 208.
} 
Woodblock 112 y 4 , y
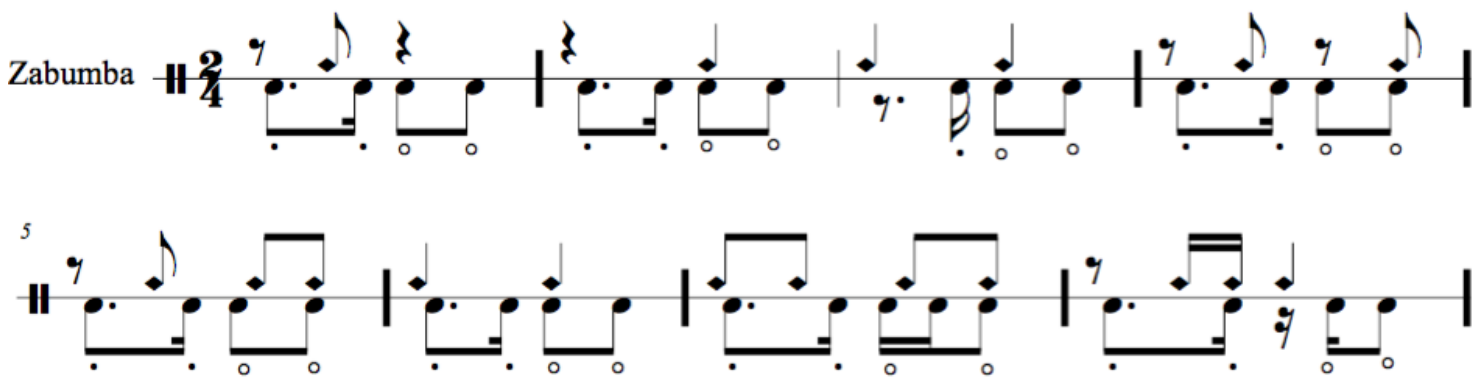

Figure 7 - Xote variations on the zabumba and woodblock

The word forró can refer to a rhythm, or to a musical genre, or to a folk

party. As a music genre, forró is the new name of the genre baião Luiz Gonzaga conceived during the 1960s. If Gonzaga was the king of baião, his pupil

Dominguinhos was named by him as the king of forró. As a rhythm, the forró is a consequence of the baião, and its variations on the zabumba are characterized by the open low sound played in the last sixteenth-note of the measure (Figure 8 ). ${ }^{38}$

Woodblock

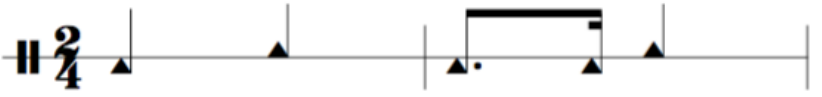

Zabumba
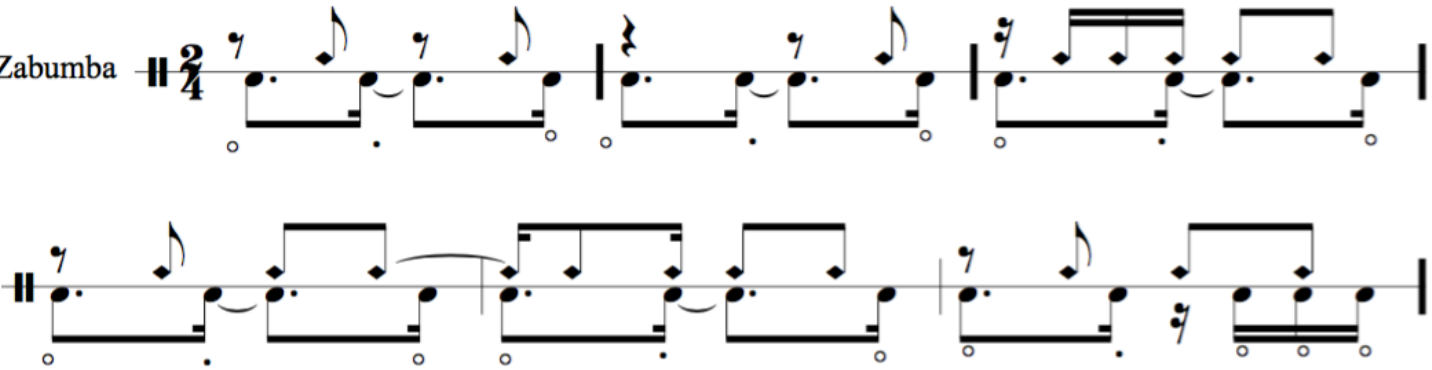

Figure 8 - Forró variations on the zabumba and woodblock

${ }^{38}$ Marcio Mattos Aragão Madeira, “A Contribuição da Música Tradicional do Cariri Cearence à Música Popular Brasileira por meio do Baião de Luiz Gonzaga” (PhD Diss., Universidad Complutense de Madrid, 2016), 223. 
Improvised solos on the accordion were featured on recordings and in live performances. On the other hand, percussion solos are rare on recordings and common on live situations. The zabumba player would break the repetitive pattern and perform syncopated phrases. Before gathering this concise trio instrumentation, Gonzaga had already recorded instrumental music featuring other instruments and rhythms as choro, polka, mazurka and waltz. The improvisation was a fundamental characteristic of these sessions, which would include solos performed mostly on the accordion, flute and sax, as well as countermelodies played on the trombone, clarinet and on the seven-string guitar. ${ }^{39}$

According to Gonzaga's pupil, singer, accordionist and composer Dominguinhos, instruments such as the electric guitar and the electric bass would eventually take the place of the cavaquinho, the acoustic guitar, the tuba and the upright bass in his band and in Gonzaga's group as well. The drum set was also incorporated at some point in Dominguinhos band, but as an additional instrument and did not take the place of the zabumba or the triangle. ${ }^{40}$

As mentioned before, Hermeto Pascoal also brought a rural cultural background from the Brazilian Northeast to an urban center in the Southeast. $\mathrm{He}$ performed instrumental music in the context of bossa-nova and samba-jazz at night clubs in São Paulo. During the 1960s, Hermeto recorded the albums Sambrasa Trio (1965) and Quarteto Novo (1967), alongside Airto Moreira, who played drum set and

${ }^{39}$ Marcio Mattos Aragão Madeira, “A Contribuição da Música Tradicional do Cariri Cearence à Música Popular Brasileira por meio do Baião de Luiz Gonzaga" (PhD Diss., Universidad Complutense de Madrid, 2016), 295.

${ }^{40}$ Ibid., 191. 
percussion in both. On the second album, the group recorded a version of Luiz Gonzaga’s song "Algodão" in addition to original compositions.

Moreover, the influence from the Northeast culture is displayed in many ways on these recordings. On the album Quarteto Novo, for instance, the instrumentation itself displays the fusion of samba-jazz with folk /Brazilian culture. Airto was encouraged by his bandmates to add folk percussion as the caxixi, triangle and pandeiro, to the drum set.

\section{2 - Airto's stylization of baião}

The album Em Som Maior (1965) by the group Sambrasa Trio is a landmark in the career of Airto Moreira, since it registered the beginning of his collaboration with Hermeto Pascoal. In this recording, it is possible to clearly identify the influence of samba-jazz on Airto's performance, and also Hermeto's influence on the arrangements. On the intro of the track "Lamento Nortista," Airto plays a variation of the xaxado groove on the drum set (Figure 9).

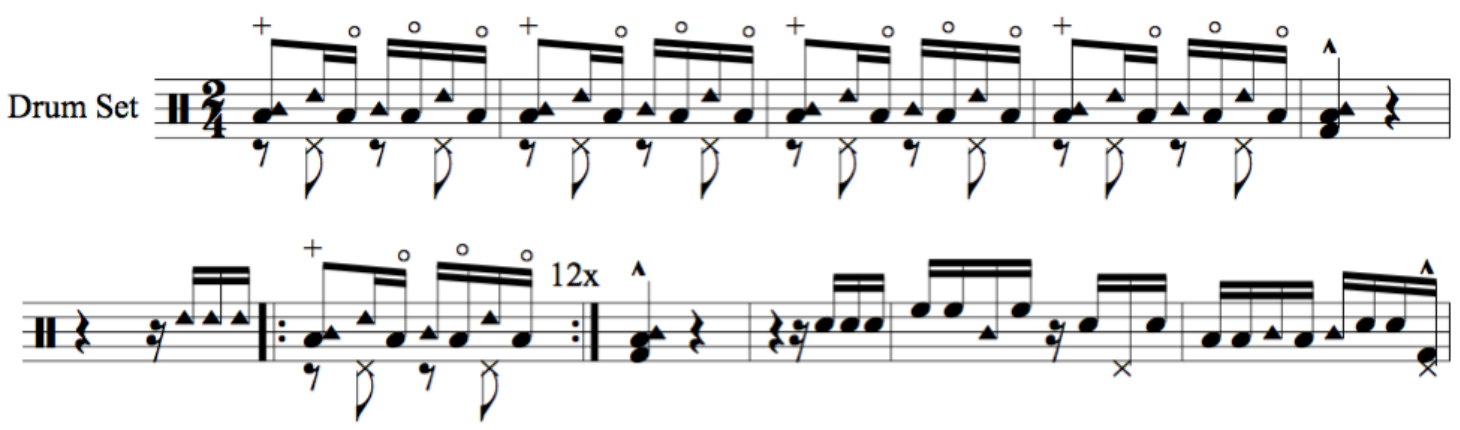

Figure 9 - Intro of "Lamento Nortista" (Em Som Maior, 1965)

In this example, he uses the floor tom as the equivalent of the low sound of the zabumba, while he extracts two different pitches from the snare rim. Airto also uses the bass drum to accent notes played on the floor tom, while keeping the hi-hats on the upbeat using the left foot. It is interesting to note that the pattern played by his 
left hand is commonly featured on the bottom head of the zabumba. However, Airto plays two different pitches, making it sound like woodblocks or agogos. The approach Airto used to stylize the baião on this track resembles how the drummers from earlier generations used to explore the instrument, looking for timbre similarities in order to translate grooves from other percussion instruments to the drum set.

The album Quarteto Novo (1967) was recorded one year later, featuring Airto and Hermeto alongside Heraldo do Monte and Theo de Barros. On this album, Airto plays percussion alongside the drum set, blending instruments as the caxixi, pandeiro, triangle and woodblocks to the American drum set, creating something one could call a Brazilian trap set. ${ }^{41}$ Although on most pieces Airto plays only percussion, there are two instances that the drum set is used to feature stylization of the rhythm baião on the tunes "Síntese" and "Vim de Sant'Ana".

The tune "Síntese" has a specifically arranged melody, followed by a section of improvisation. The arrangement itself seems to be the result of a collective collaboration, where each musician has some freedom to build phrases aiming to enhance the melody. ${ }^{42}$ Airto plays with brushes the entire arrangement, exploring the timbre possibilities around the drum set using the bristles on the drumheads and the bottom of the brushes on cymbals and woodblocks.

\footnotetext{
${ }^{41}$ Guilherme Marques Dias, Airto Moreira: do samba-jazz à música dos anos 70 (1964-1975), (Master thesis, Campinas, UNICAMP, 2013), 160.

${ }^{42}$ Ibid., 93.
} 

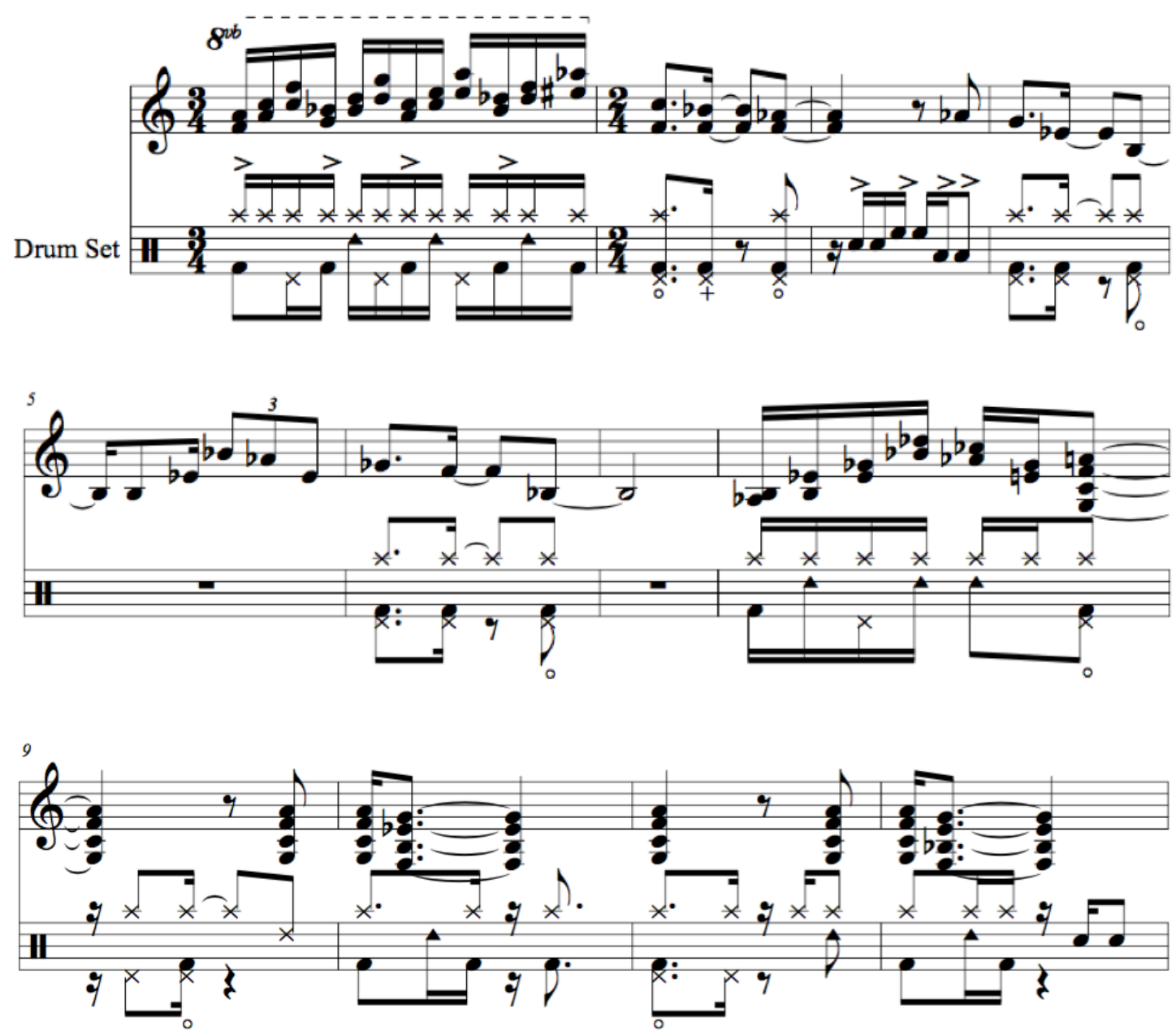

Figure 10 - mm. 1-12 of "Síntese" - Quarteto Novo, 1967. (treble staff transcribed from Simões, p. 81)

On the first twelve bars, Airto plays the drum set to enhance the melody, reinforcing its contour by filling spaces or playing motives in unison (Figure 10). At this point, the arrangement does not yet allow the listener to perceive a clear statement of a specific folk rhythm.

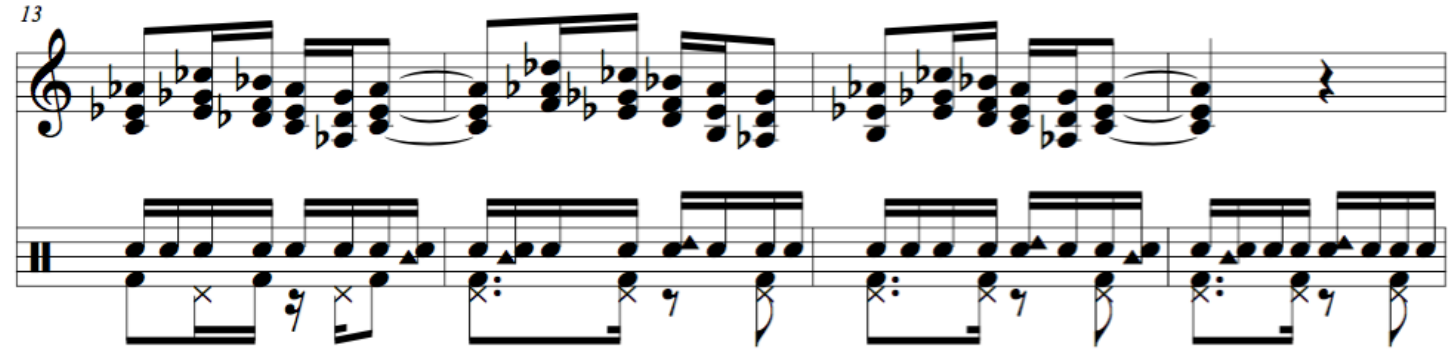




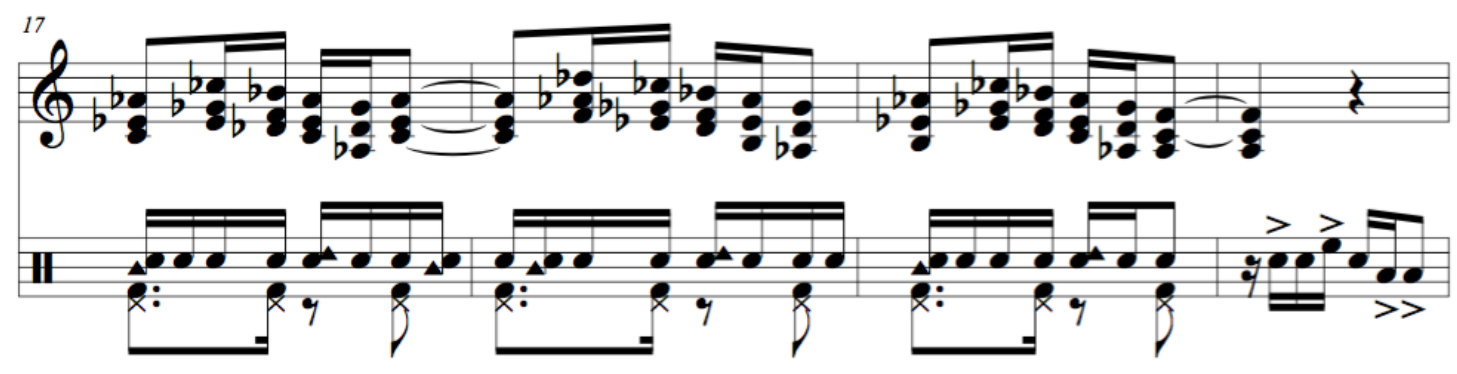

Figure 11 - mm. 13-20 of "Síntese" - Quarteto Novo, 1967. (treble staff transcribed from Simões, p. 81)

From measures 13-20, Airto states clearly the patterns of a xaxado groove on the hi-hats and bass drum, while he plays sixteenth-notes with the brush on the snare using one hand, and a syncopated pattern on the woodblocks with the other hand (Figure 11). The pattern featured on the woodblocks by Airto is not strictly the same found on recordings by Luiz Gonzaga. However, it keeps the low pitch on beat one and the high pitch on beat two, and clearly relates to the patterns usually played on the bottom head of the zabumba in forró grooves.
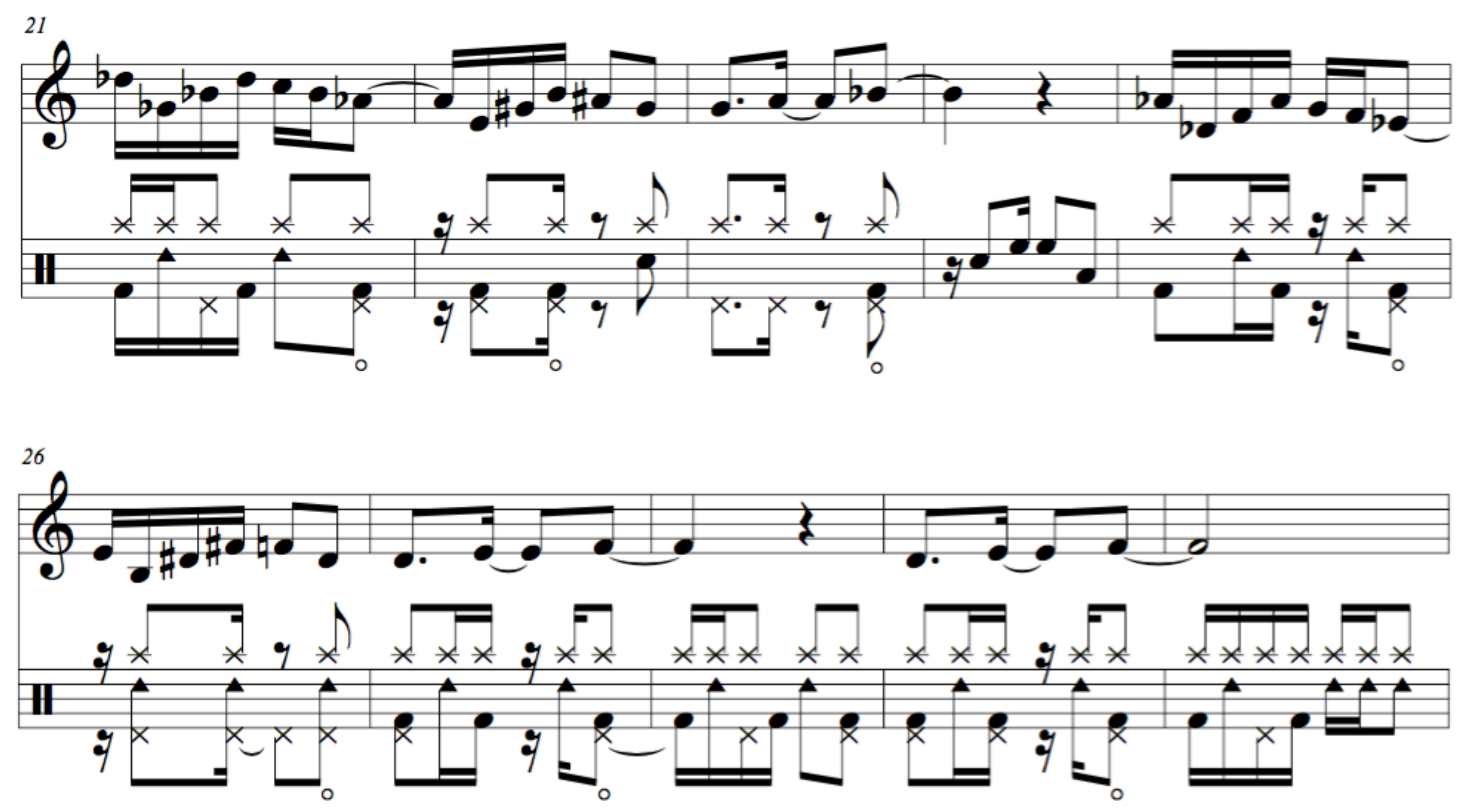

Figure 12 - mm. 21-30 of "Síntese" - Quarteto Novo, 1967. (treble staff transcribed from Simões, p. 81) 
From m. 27 on, Airto starts to settle the groove for the solo section (Figure 12). Airto's use of the hi-hat on this tune is an example of the influence by North American jazz drummers on his performance. As mentioned by Brazilian drummer Pascoal Meireles, Airto assimilated the way renowned North American jazz drummers like Tony Williams started to use the left foot to comp during the 1960s, and transposed this interactive approach to Brazilian musical styles. ${ }^{43}$

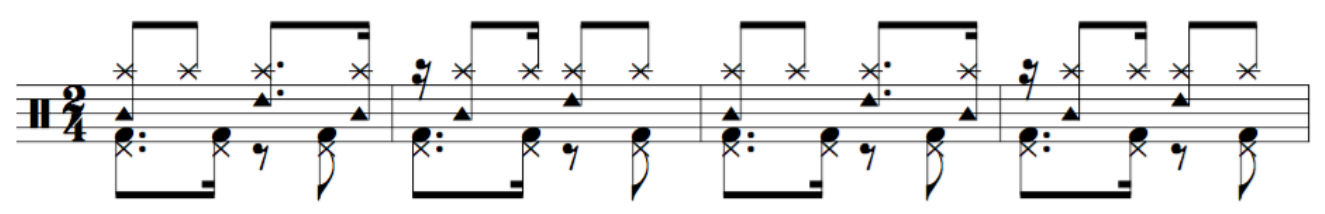

Figure 13 - Groove for solo section of "Síntese" - Quarteto Novo, 1967

For the solo section, Airto played a sparser groove, with the hi-hat and bass drum playing a characteristic xaxado ostinato in unison, while using the bottom tip of the brushes to play a slightly different ostinato on the woodblocks and the ride cymbal (Figure 13). Comparing this example to the transcription of Edison Machado's samba on "Quintessência," 44 it is possible to find similarities between the ride cymbal patterns. Moreover, it displays a structure that can be correlated to a recurrent samba pattern usually played on the tamborim, known as teleco-teco (Figure 14). ${ }^{45}$

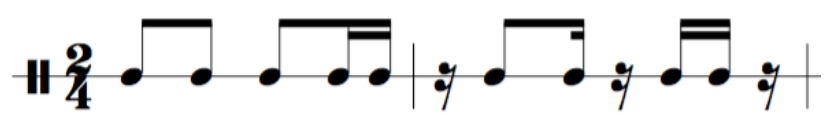

Figure 14 - Teleco-teco pattern

${ }^{43}$ Guilherme Marques Dias, “Airto Moreira: do Samba-jazz à Música dos Anos 70” (Master Thesis, Universidade de Campinas, 2013), 85.

${ }^{44}$ See transcription on page 13.

${ }^{45}$ Vinícius de Camargo Barros, "O Uso do Tamborim por Mestre Marçal: Legado e Estudo Interpretativo" (Master Thesis, Universidade de Campinas, 2015), 71. 
Although one cannot assume that this groove is a conscious merging of samba and xaxado, this example demonstrates that drum set stylizations can often be ambiguous.

On the tune "Vim de Sant'Ana," recorded during the same session, Airto made an interesting stylization of a forró groove (Figure 15). He used a brush to play sixteenth-notes on the snare head, splitting the forró pattern between the right foot on the bass drum and the left hand on the snare rim using a stick.

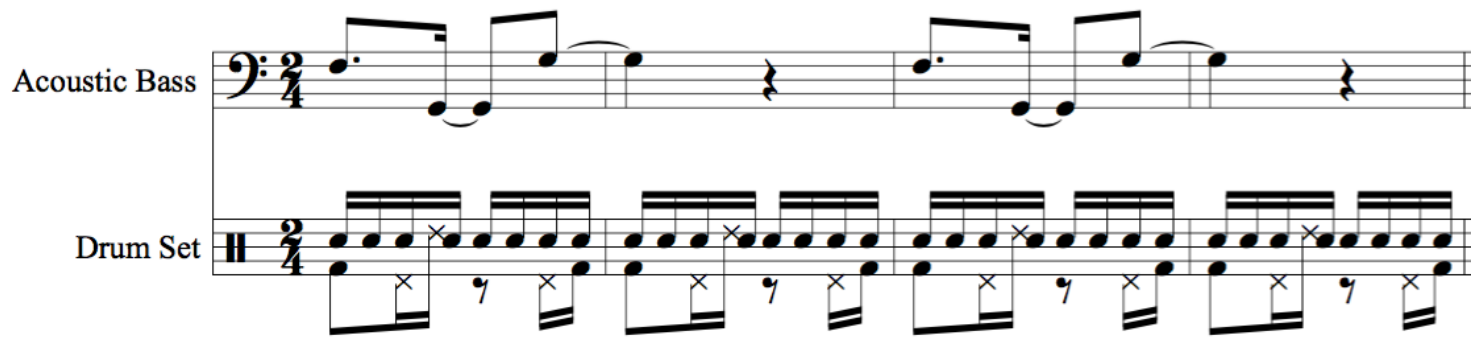

Figure 15 - Stylization of forró on tune "Vim de Sant'Ana"

The tune "Misturada," features a stylization of samba in 7/4 over the exposition of the melody, as well as a drum solo on which Airto plays a xaxado pattern on the bass drum in the same meter (Figures 16 and 17).

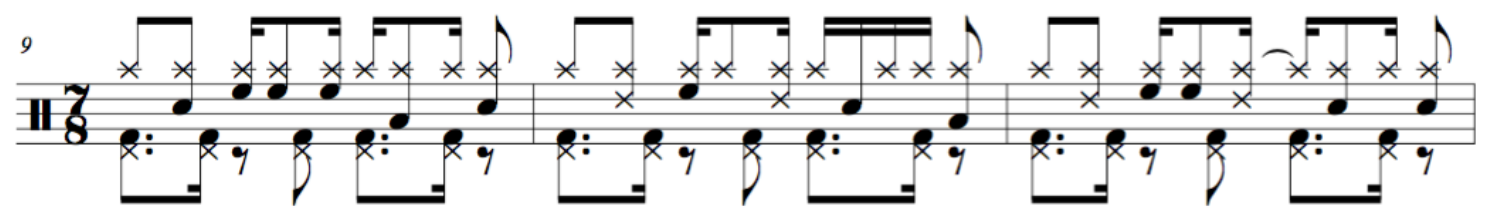

Figure 16 - mm. 9 - 11 of Airto's solo on "Misturada" 

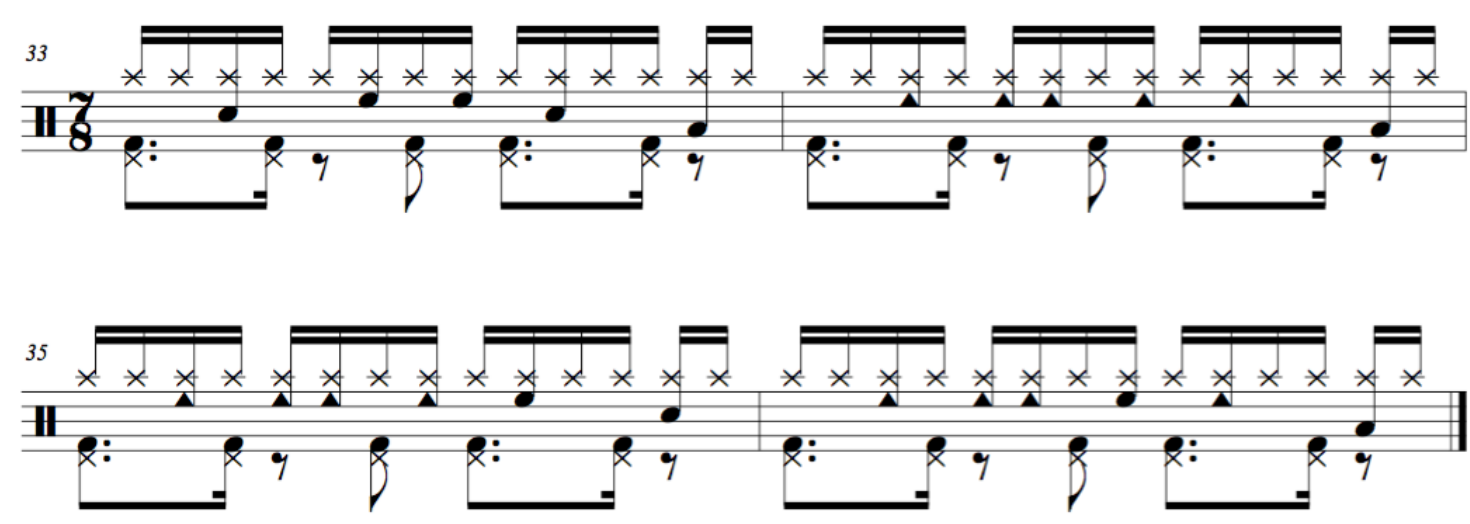

Figure 17 - mm. 33 - 36 of Airto's solo on "Misturada"

Again, Pascoal is an important figure regarding the drummer's performance.

Since Brazilian drummers in the context of samba-jazz would typically play solos using vocabulary borrowed from North American jazz drummers, Hermeto used to challenge them to build their solos using musical material characteristic of samba or other Brazilian style. ${ }^{46}$

On the recording session of the album Quarteto Novo, Airto did not use any overdubs to combine percussion and the drum set, approaching this combination of instruments as a Brazilian trap set. He explained that, he recorded everything nonstop, and had to manage details in his performance such as changing his position on the set when playing only percussion. ${ }^{47}$ Years later, Airto would have a different approach when merging the drum set and percussion. After moving to the USA, Airto had the opportunity to record several albums as a leader, with overdubs in his arrangements. In this case, he would combine rhythm stylizations on the drum set with overdubs of

${ }^{46}$ Guilherme Marques Dias, "Airto Moreira: do Samba-jazz à Música dos Anos 70" (Master Thesis, Universidade de Campinas, 2013), 156.

${ }^{47}$ Ibid., 158. 
Brazilian percussion instruments. The track "Arroio," recorded in 1972 and released on the album Free (1973), features an example of this approach.

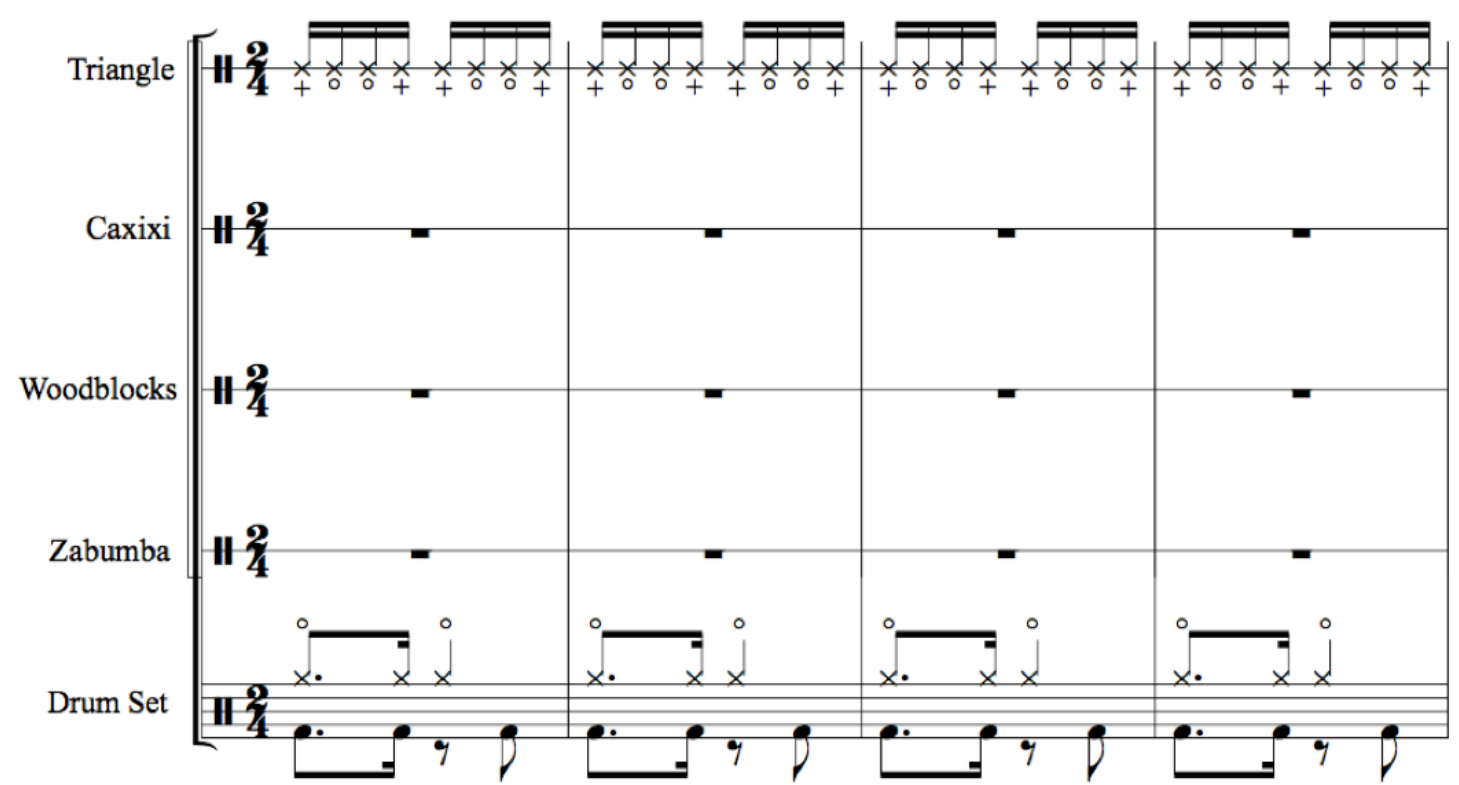

Figure 18 - mm. 1-4 from intro of "Arroio" from album Free (1973)

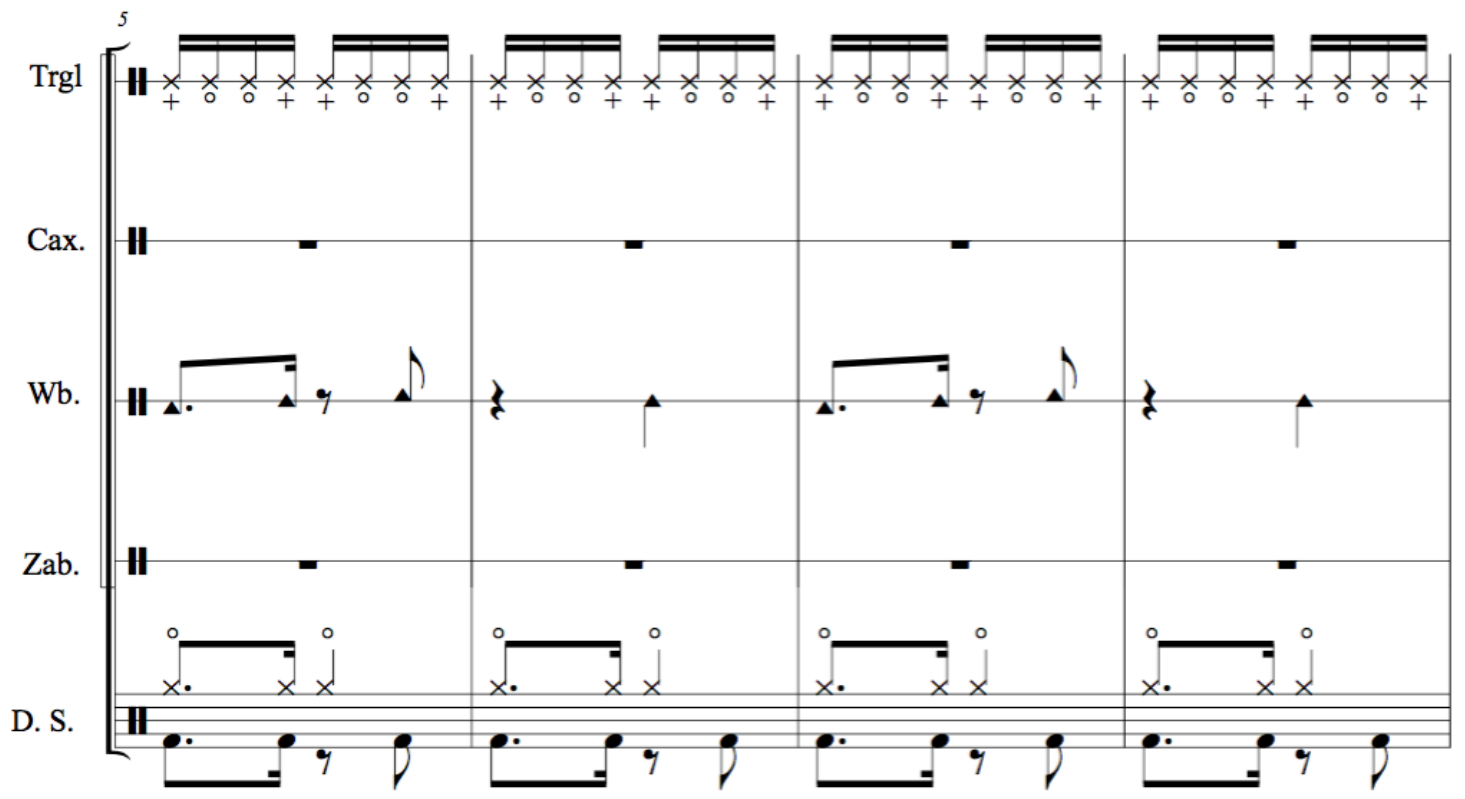




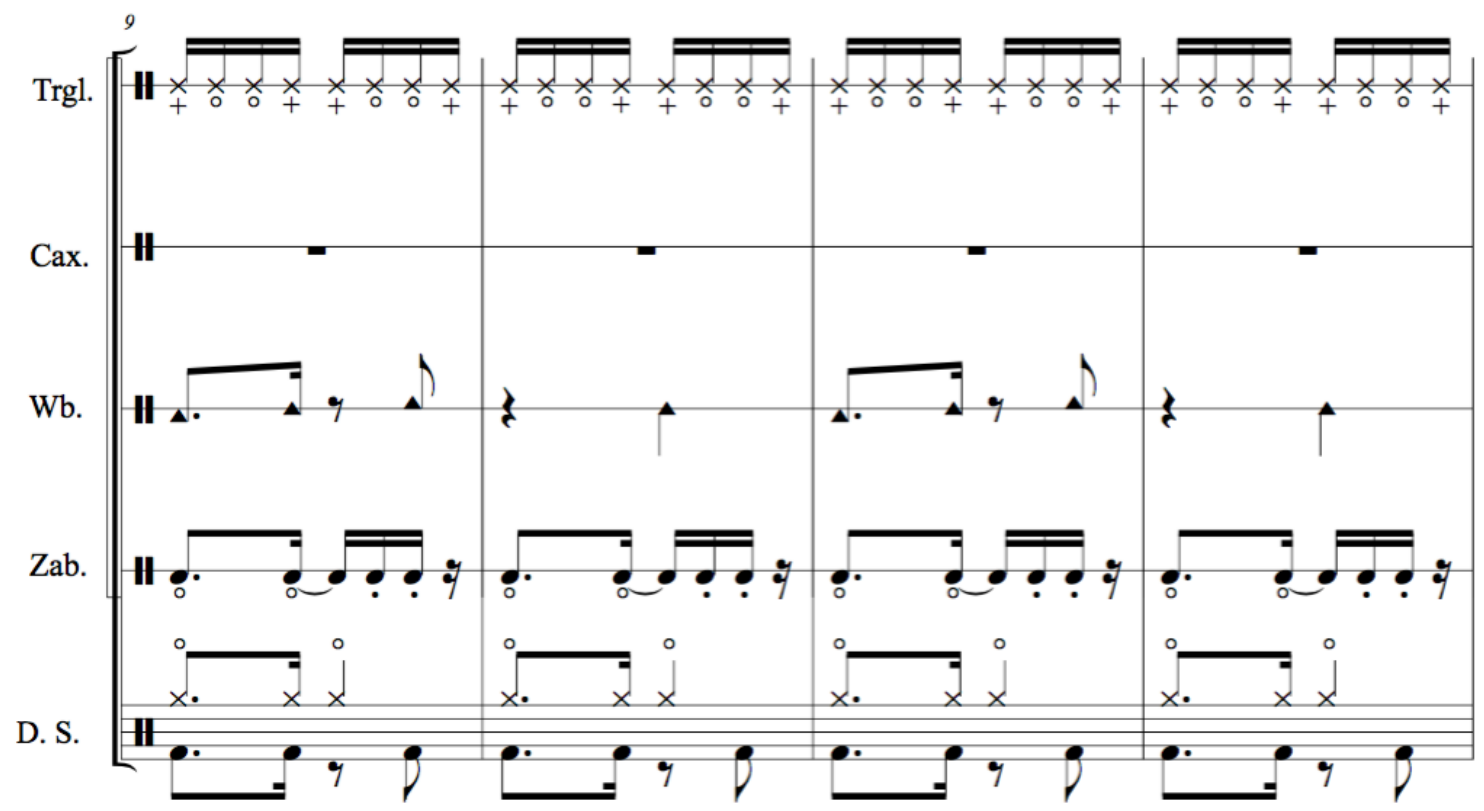

Figure 19 - mm. 5-12 from intro of "Arroio" from album Free (1973)

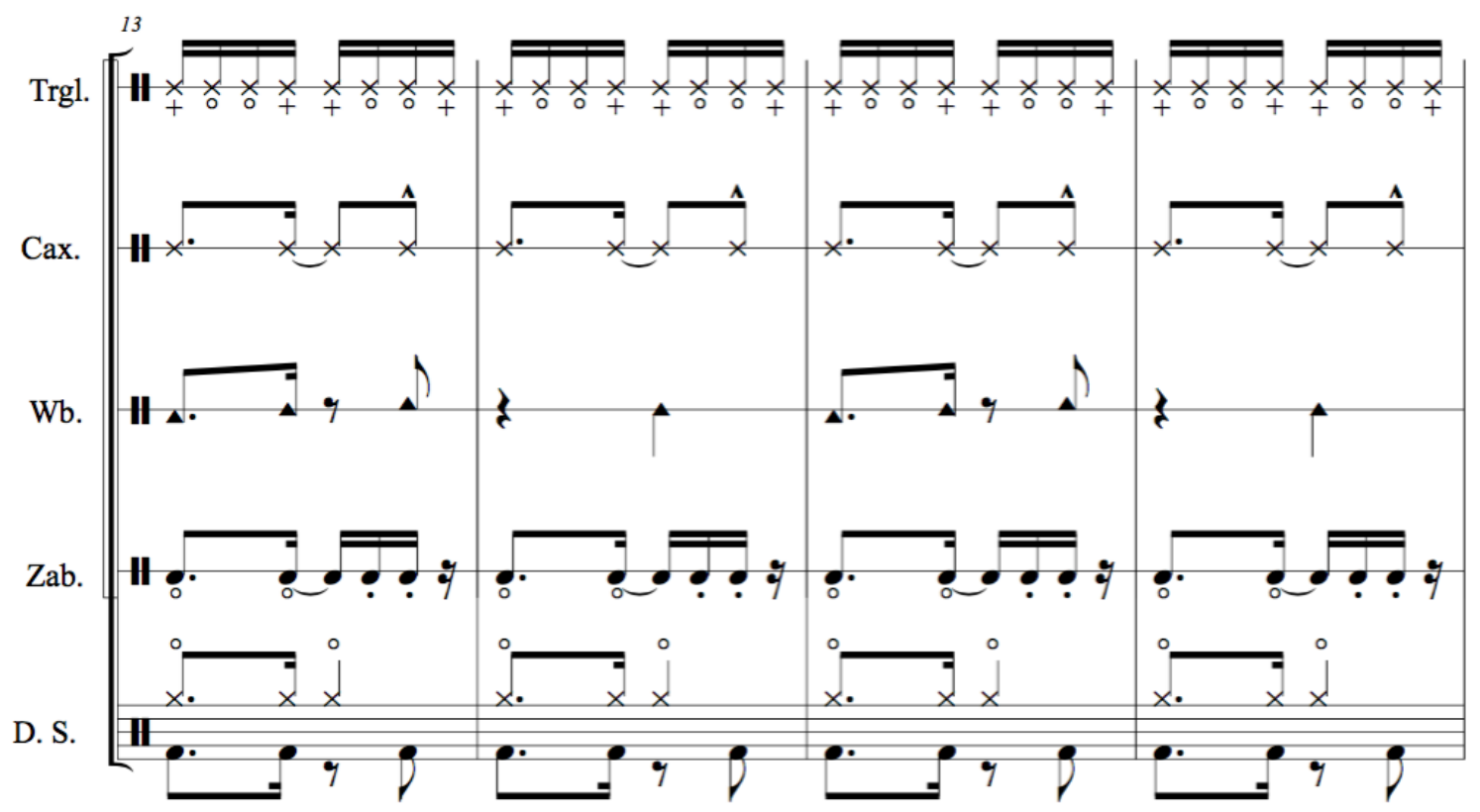




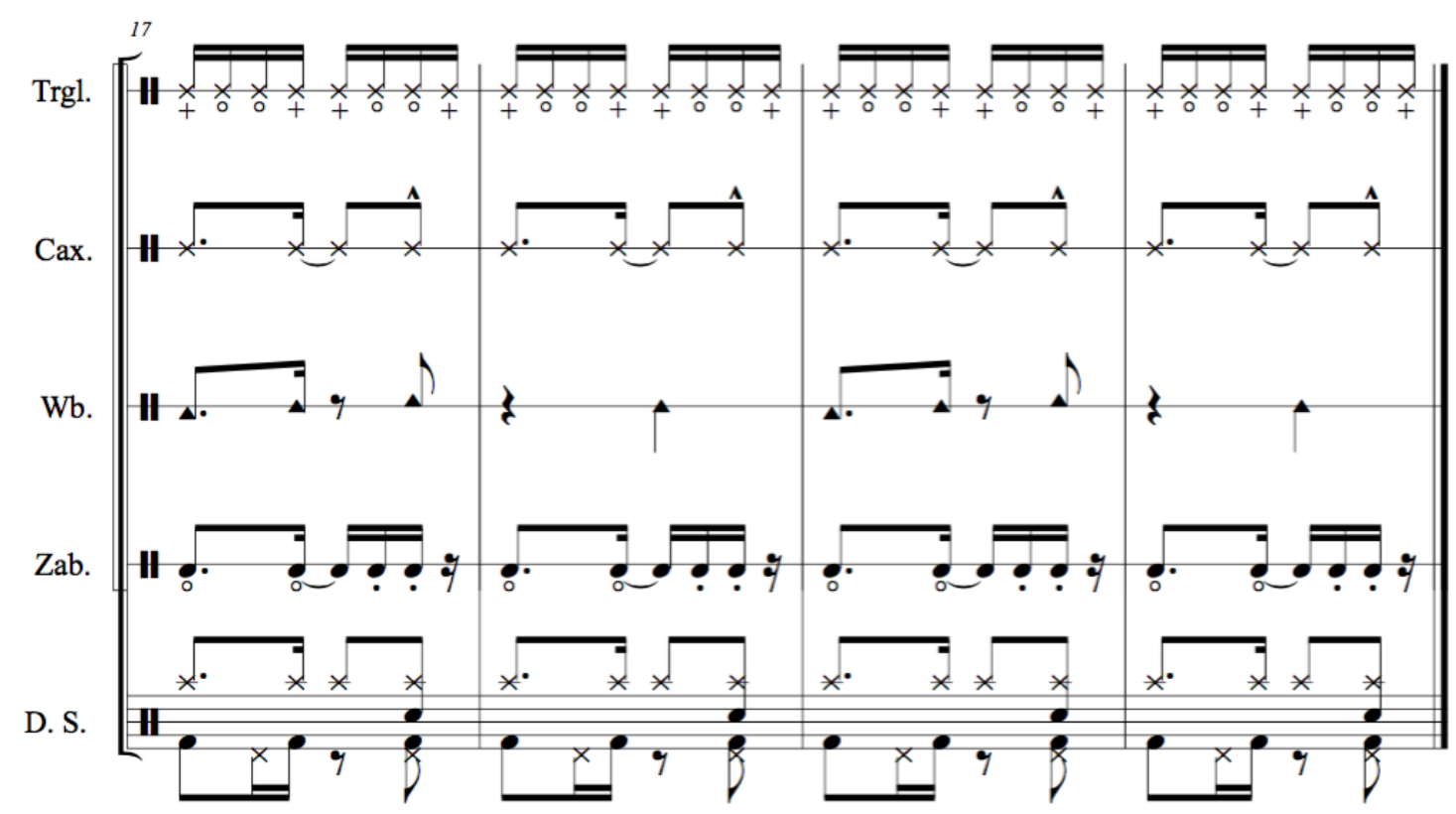

Figure 20 - mm. 13-20 from intro of "Arroio" from album Free (1973)

On the intro, Airto's arrangement starts with a drum set and triangle, and adds a layer of percussion each four bars. In this scenario, Airto saves room for the zabumba, caxixi and woodblock, by playing only hi-hat and bass drum on the drum set. Only on the last four bars before the melody, Airto adds the ride cymbal and the snare drum (Figure 20).

It is interesting to compare this version to the bonus track recorded on the same session and released on CD in 2003, since the last features Airto playing drum set with no percussion overdubs. On this take, Airto has more space to build a baião stylization and to interact with the soloists. Over the intro, as well as during the first exposition of the melody, Airto plays the baião pattern on the bass drum, playing the hi-hats on every upbeat. On top of that, he uses the ride cymbal to drive the band. He also adds the snare drum, featuring almost the same pattern he played on the woodblocks over the solos of "Síntese" (Figure 21). 


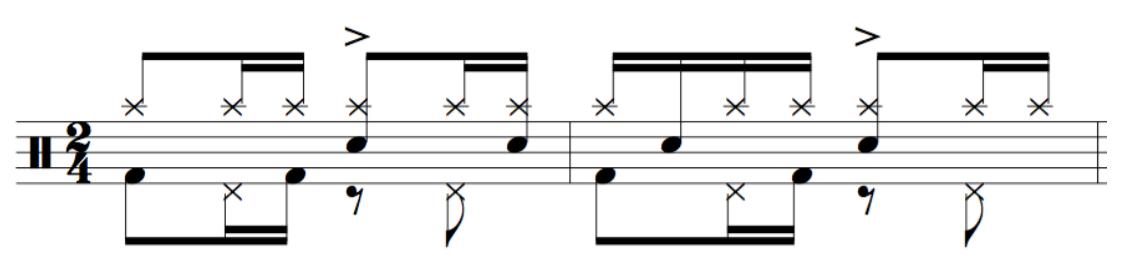

Figure 21 - Drum set groove on alternate take of tune "Arroio"

During the second time of the melody exposition, Airto adds sixteenth-notes played on the tom every other measure. This detail enhances the form contour, as well as increases the energy (Figure 22).

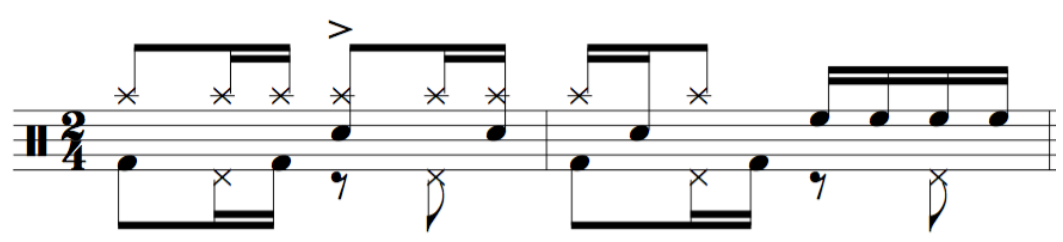

Figure 22 - Variation of drum set groove on alternate take of tune "Arroio"

After the melody, Airto plays another baião variation over this short section that works as an interlude to the solos (Figure 23).

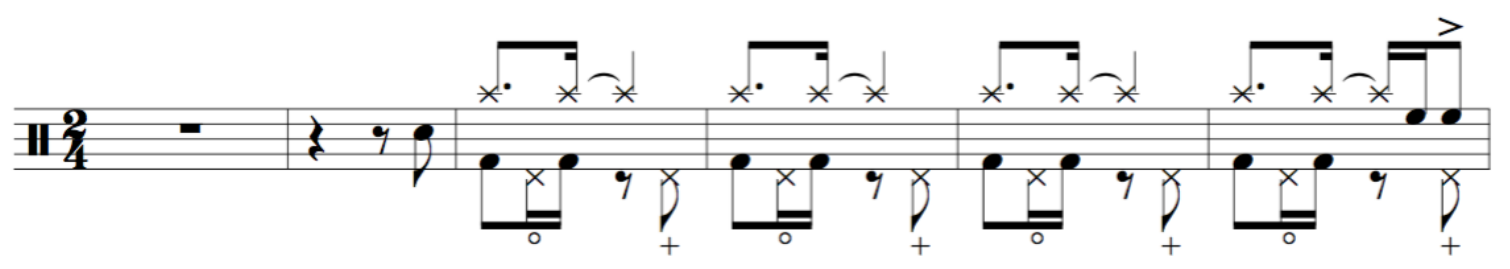

Figure 23 - Drum set groove during interlude on alternate take of tune "Arroio"

During the solos, Airto's comping does not stray far from the grooves previously performed over the melody. He adds a bass drum to the groove on every second beat, as in a xaxado pattern (Figure 24). 


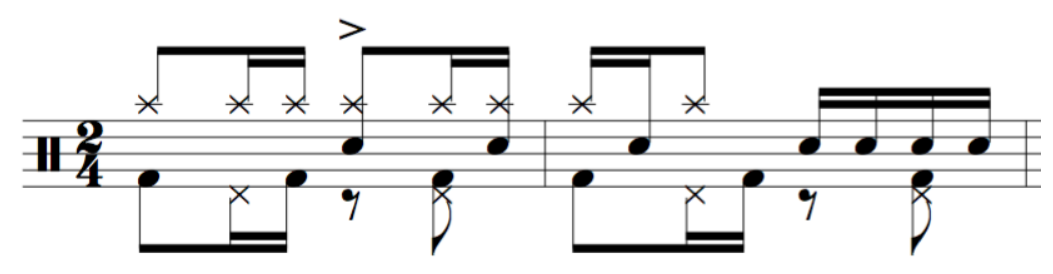

Figure 24 - Drum set groove during solos on alternate take of tune "Arroio"

Although these exact patterns are not usually combined in a groove played by a characteristic baião percussion ensemble, Airto's stylizations of this genre on the drum set feature several characteristics in common to its source. Overall, the variations played on the bass drum are key to distinguishing the baião rhythms among themselves, as well as from the stylizations of other Brazilian rhythms, like the samba, the maracatu, and the frevo.

\section{3 - Nenê's stylization of baião}

According to Nenê, Edison Machado only played samba, bossa-nova and jazz. Also, drummers from the generation before him, such as Luciano Perrone, would perform stylizations of baião and other rhythms from Northeast Brazil in a limited way, emulating the sounds they heard from the zabumba, for example.

Hermeto Pascoal had a major impact on drummers that performed alongside him. He taught them how to play rhythms from Northeast Brazil on the drum set by singing the patterns, or playing his own stylizations on the kit. After showing Nenê a rhythm, Hermeto would encourage him to create a new stylization on the instrument. 
Following Hermeto's advice, he explored the possibilities the drum set offers, referring to the musical source by keeping the accents of the source's patterns. ${ }^{48}$

The track “Suite Norte, Sul, Leste, Oeste," recorded by Hermeto's group in the album Zabumbe-Bum-Á (1979), is a suite composed of four themes, and Nenê plays different baião and xaxado variations throughout them (Figure 25).
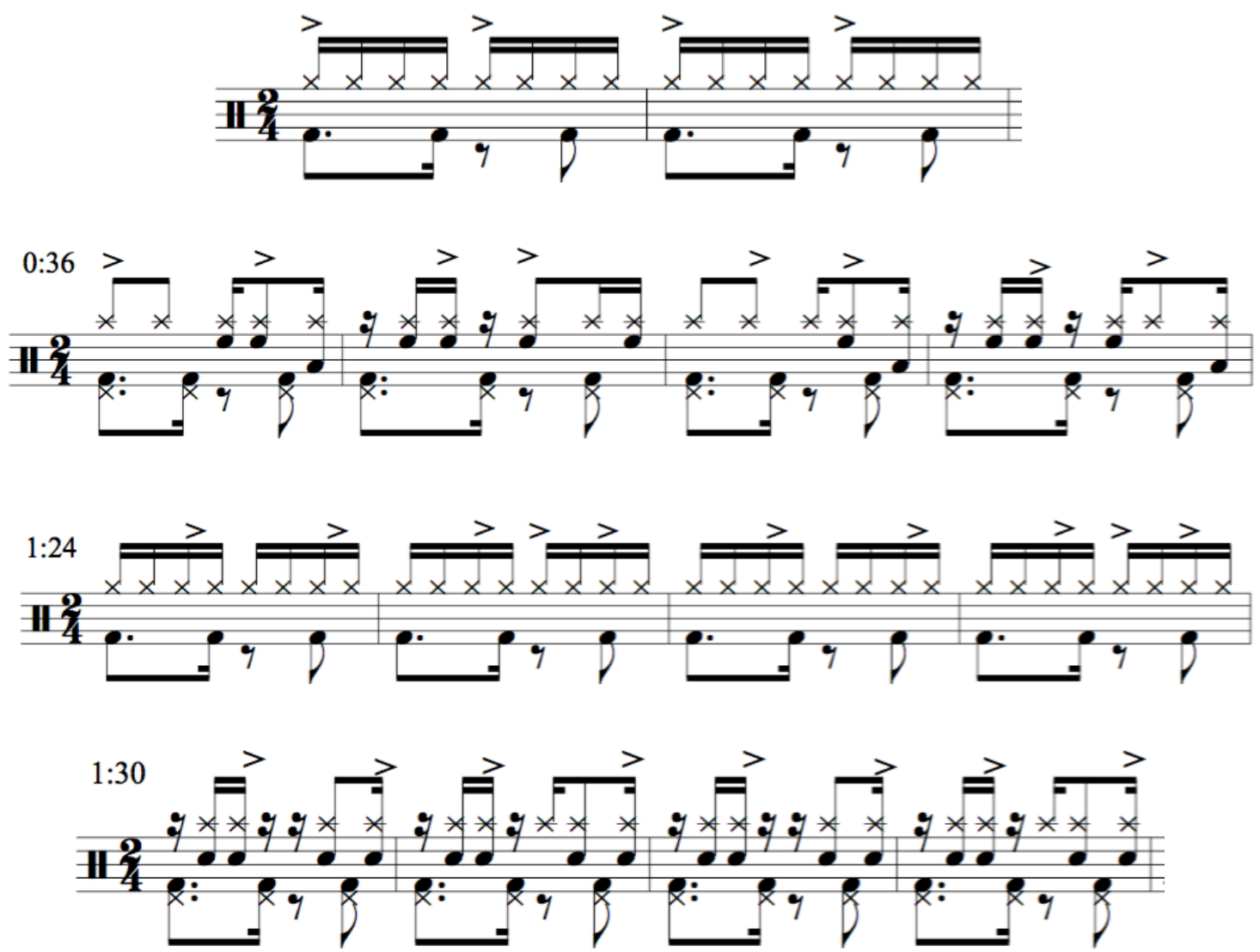

Figure 25 - Nenê's stylizations of baião on the tune "Suite Norte, Sul, Leste, Oeste"

The examples above (Figure 25), show that Nenê centers his stylizations on the bass drum pattern, while he uses his hands to find different colors and patterns around the drum set, also alternating sticking and the placement of accents.

${ }^{48}$ Guilherme Marques Dias, "Airto Moreira: do Samba-jazz à Música dos Anos 70" (Master Thesis, Universidade de Campinas, 2013), 106. 
On the tune "Lorô" from the album Sanfona (1981) by Egberto Gismonti's group, Nenê performs variations of xaxado and baião (Figure 26).
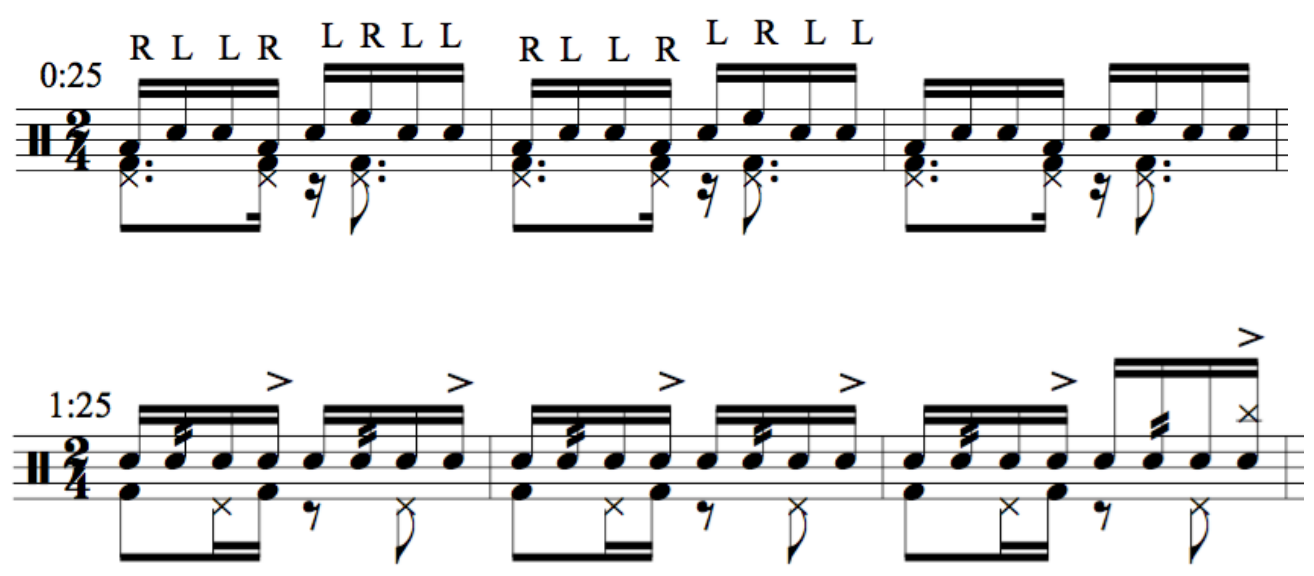

Figure 26 - Nenê's stylizations of baião on the tune "Loro"

The groove Nenê performs at 0:25 of the tune "Loro" is built on the pattern played on the bass drum and hi-hat, having the right hand matching the same rhythm, while the left hand fills the space in between using the snare drum (Figure 25).

Overall, Nenê builds his baião stylizations around the bass drum pattern, using the hands to fill spaces and add colors to the groove. Also, his efforts to perform these rhythms on the drum set feature enough similarities so a careful listener can recognize these stylizations as representative of the genre.

\section{4 - Márcio Bahia’s stylization of baião}

The tune "De Sábado para Dominguinhos," released on the álbum Só Não Toca Quem Não Quer (1992), features a medium tempo baião. In the context of this recording, Bahia often explores the possibilities within one piece of the drum set, leaving space to the percussion layer (Figure 27). 

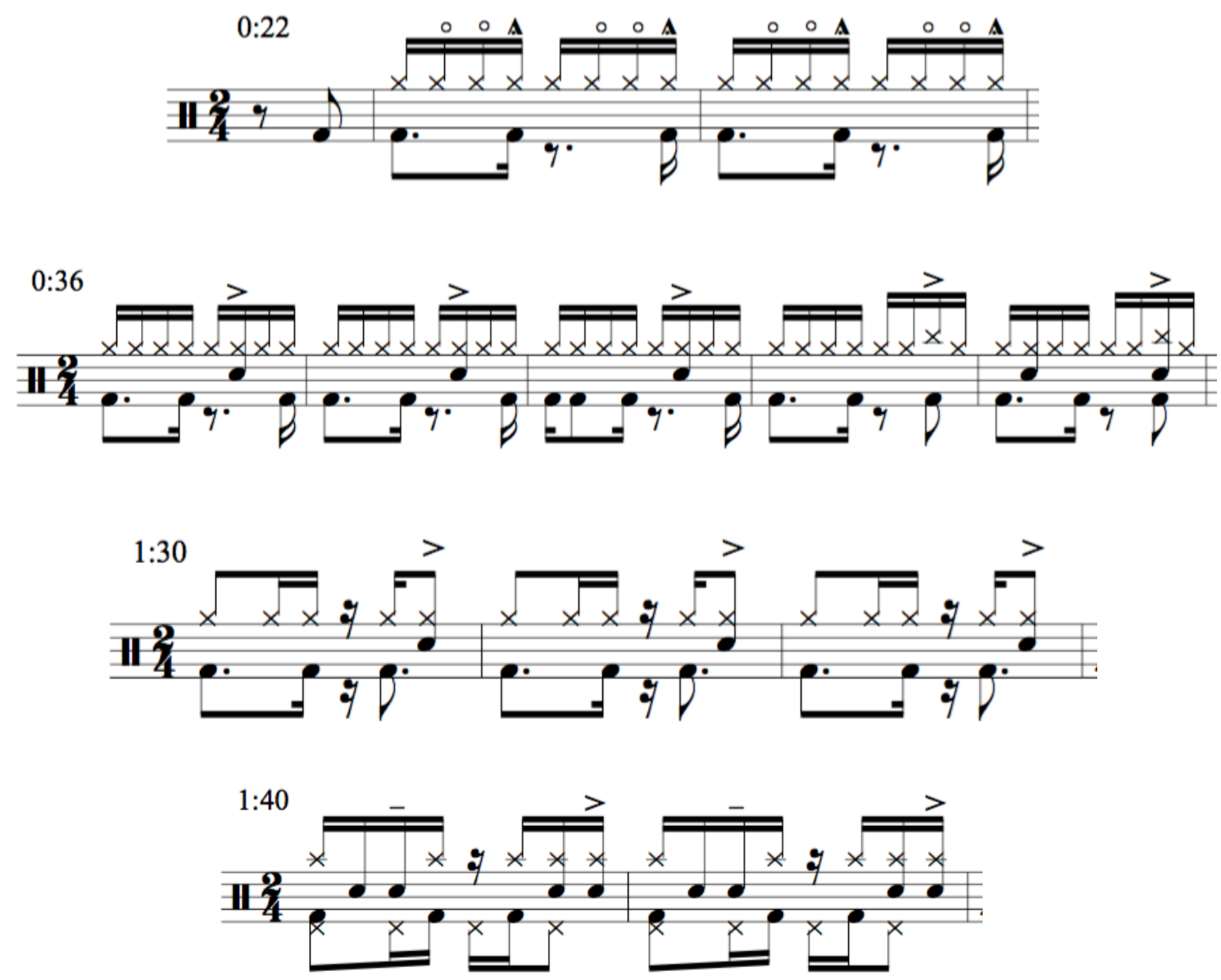

Figure 27 - Márcio Bahia's stylizations of baião on "De sábado pra Dominguinhos"

Other interesting baião stylizations by Marcio Bahia are featured in the context of Hamilton de Holanda's quintet. On the tune "Baião Brasil," Bahia uses brushes on the snare, using one of his hands to swap the brush, while the other plays accents (Figure 28). This stylization features the bass drum playing the downbeat and the snare playing an accent on the last sixteenth-note of the first beat, while he plays the hi-hat with the foot to keep a pattern.

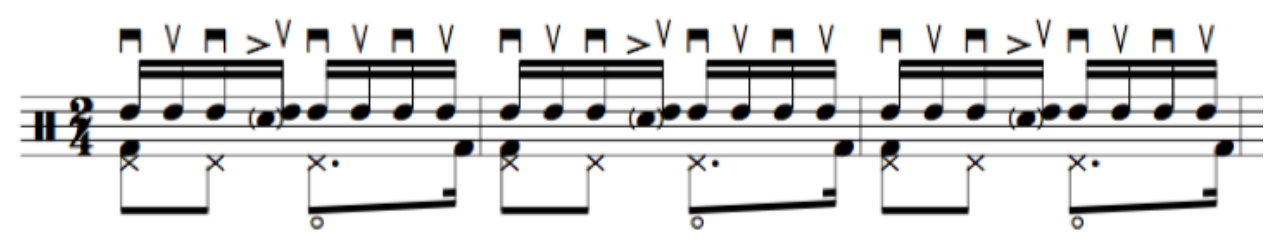

Figure 28 - Márcio Bahia’s stylization of baião on tune "Baião Brasil" 
The version of the tune "Vera Cruz," released on the album Casa de Bituca (2017), also features a Bahia stylization that goes further when exploring the variations of baião (Figure 29). On this session, Márcio performs subtle variations around the toms and snare while keeping the core of the groove using his feet and the accents on the snare. This particular groove can sound ambiguous to some listeners, since the bass drum and hi-hat patterns added to the snare accents sound similar to the characteristic drum set samba ostinato known as bumbo-à-dois ${ }^{49}$. However, in order for this groove to sound like a samba stylization, the bass drum would be played on every beat two, instead of the downbeat. Also, the variations played on the snare rim are commonly featured on the zabumba.

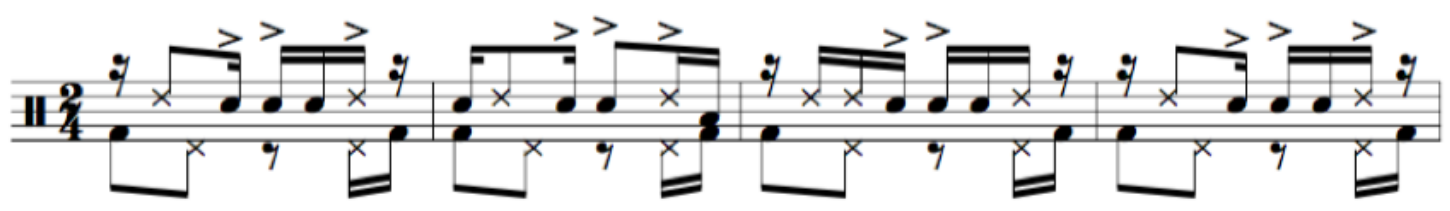

Figure 29 - Márcio Bahia's stylization of baião on tune "Vera Cruz"

${ }^{49}$ See page 12. 


\section{CHAPTER 4 - MARACATU}

\section{1 - The genre maracatu}

Maracatu is a social-cultural expression related to African religious roots. It has been studied since the first decades of the last century, and its origins are frequently affirmed by researchers as purely African, meaning that it is a religious manifestation that kept all its characteristics when brought from the other continent to be reproduced in South America. However, scholars have found more recently that it is just impossible to track back a similar tradition from Africa, and it is more likely that the maracatu is a result from a complex blend of different African cultures that took form between the $19^{\text {th }}$ and $20^{\text {th }}$ century, and is continuously evolving in the Brazilian Northeast. ${ }^{50}$

There are many different kinds of maracatus, and they diverge from each other regarding the instrumentation of its musical ensembles, the music itself, the rituals, the apparel, and the religious roots and the environment where each one of them evolved. The geographical factor is concerning to cultural characteristics from different states of the Brazilian Northeast where the maracatu had evolved, as well as the urban versus the rural environment.

The maracatu from the city of Recife has its tradition carried and evolved by different neighborhoods, and it is known as maracatu-nação or maracatu de baque-

${ }^{50}$ Ivaldo Marciano de França Lima, "Entre Pernambuco e a África. História dos Maracatu-nação do Recife e a espetacularização da Cultura Popular" (PhD Diss., Universidade Federal Fluminense, 2010), 62. 
virado. The maracatu from rural communities is named maracatu de baque-solto. There are differences between the music made in maracatus from the city and rural area, as well as in between each neighborhood in the city. Each neighborhood has its nação featuring different songs and rhythmic peculiarities, creating different musical identities within common patterns in the instrumentation. For the purpose of this research, it is essential only to examine the characteristics of the music made by the percussion ensembles of the maracatu-nação, since this was the source from where musicians as Egberto Gismonti and Hermeto Pascoal have drawn inspiration to create instrumental music that reflected on the drum set vocabulary.

The music made in maracatus-nação features only voice and percussion. The vocalized part consists of a lead voice and a chorus, using mostly call-response technique in the arrangements. The percussion ensemble is traditionally composed of caixas-de-guerra (similar to snare-drums), gonguê (resembles the well-known cowbell), mineiro (a specific shaped shaker) and low tuned drums made in different sizes, called alfaias. Recently, some maracatus have added the atabaque and the abê to its instrumentation. ${ }^{51}$ Each nação has its history; some emerged after the 1970s and others were created by the end of the $19^{\text {th }}$ century.

The maracatu groove can feature different variations regarding the patterns played by each percussion instrument. The transcriptions below feature rhythm patterns and variations common to percussion ensembles of many different nações.

${ }^{51}$ Ivaldo Marciano de França Lima, "Entre Pernambuco e a África. História dos Maracatu-nação do Recife e a espetacularização da Cultura Popular” (PhD Diss., Universidade Federal Fluminense, 2010), 41. 
Examples of these grooves and variations can be heard in recordings by the Nação Estrela Brilhante, ${ }^{52}$ and the Nação Leão Coroado (Figure 30). ${ }^{53}$
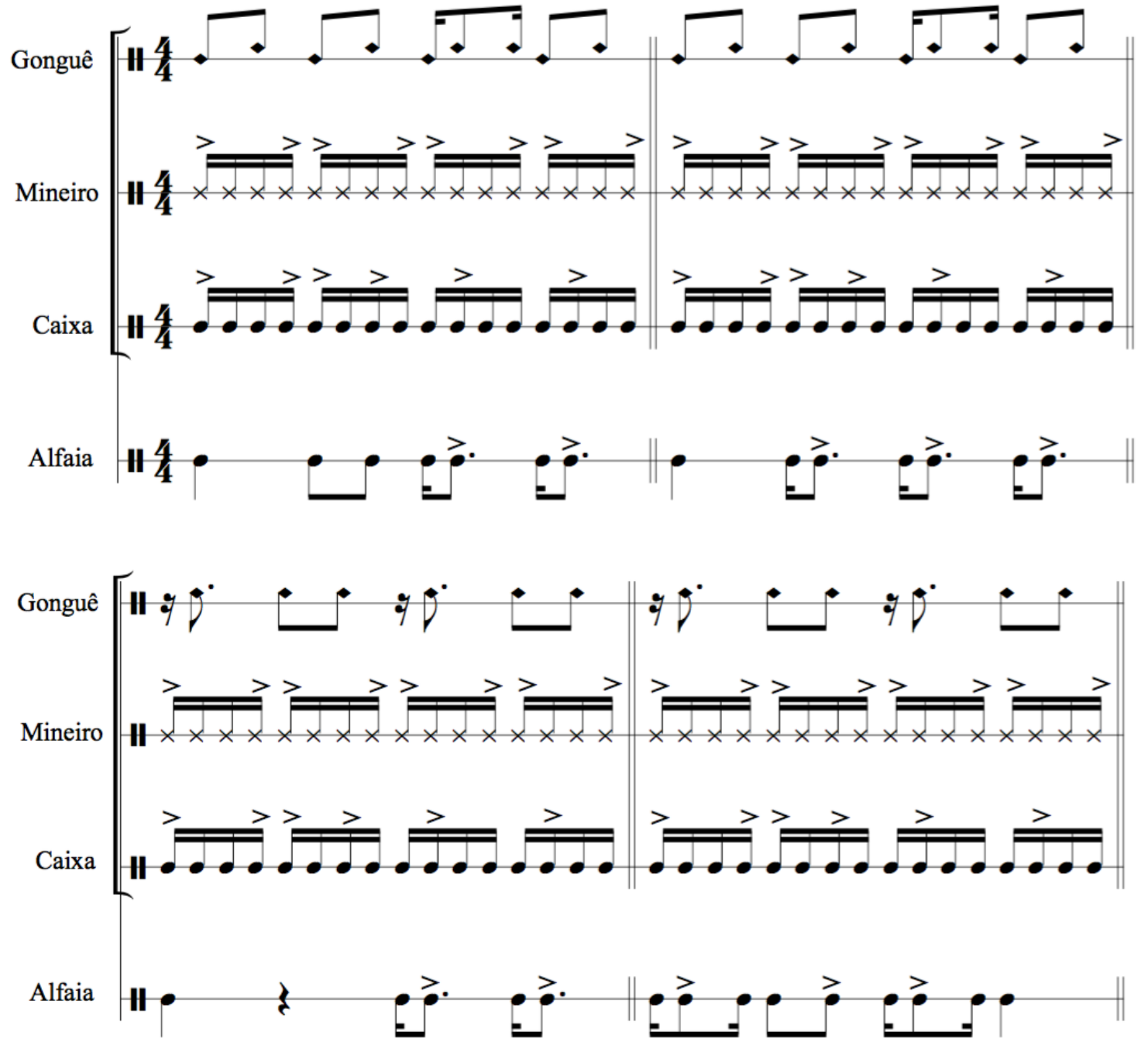

Figure 30 - Common variations of maracatu groove played by percussion ensemble

${ }^{52}$ Maracatu Nação Estrela Brilhante, "Baque Virado/ Toada (Maracatu Nação)" Instrumentos Populares do Nordeste, MPL 9.346, 1976, Vinyl.

${ }^{53}$ Wagner Simões, "Maracatu Leão Coroado," filmed 1987 at Recife, PE, Brazil, video, 18:15, accessed March 14, 2019,

https://www.youtube.com/watch?v=M9cE ng39M 
It is important to note that there are nowadays more than twenty-five nações in Recife, in opposite to only five existing during the 1970 s. ${ }^{54}$ As a consequence, percussive ensembles similar to the maracatu-nação, but with no religious root, emerged in other cities around the country and the world, as clear examples of the inception of this music in the world music market. ${ }^{55}$

In this context, a Brazilian band from Recife, named Nação Zumbi, represents an opportune example regarding the presence of maracatu in the world music market. The band started a musical movement known as Mangue Beat, which blended rhythms and percussion instruments from the maracatu, with influences from rock and surf-music, making great success in the 1990s. Before that, Egberto Gismonti had recorded the album Sanfona (1981), bringing rhythm patterns characteristic of maracatu to the context of instrumental music. Nenê is the drummer who recorded the album, having the opportunity to create stylizations of the maracatu and other Brazilian folk rhythms as baião, xaxado and frevo.

\section{2 - Nenê's stylization of maracatu}

On the tune "Maracatu," from the album Sanfona (1981), Nenê plays an interesting stylization of maracatu (Figure 31). He plays the characteristic pattern of maracatu on the bass drum and toms, filling the space within the pattern using the snare and ride cymbal. Again, Nenê uses the right hand to play different colors around the drum set, while he plays the snare drum with the left-hand to fill space and add texture to the groove.

\footnotetext{
${ }^{54}$ Ivaldo Marciano de França Lima, "Entre Pernambuco e a África. História dos Maracatu-nação do Recife e a espetacularização da Cultura Popular" (PhD Diss., Universidade Federal Fluminense, 2010), 25.

${ }^{55}$ Ibid., 26.
} 


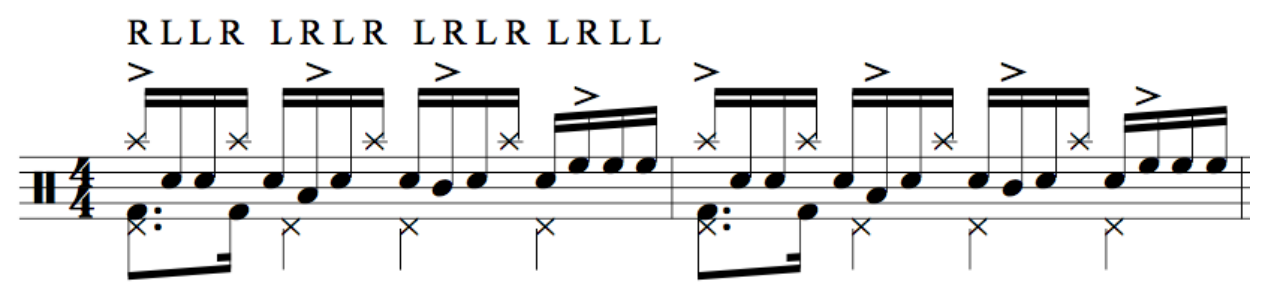

Figure 31 - Nenê's stylization of maracatu on tune "Maracatu"

The following maracatu stylizations are featured on his method book for drum set (Figure 32 and 33), Brazilian Drum in the $21^{\text {st }}$ Century by Nenê (2008). On these examples, there is a gonguê pattern to be played on cowbells or woodblocks. Also, on the first example, the ostinato bumbo-à-dois, common of samba stylization, is combined with a maracatu characteristic pattern played on the toms (Figure 32).

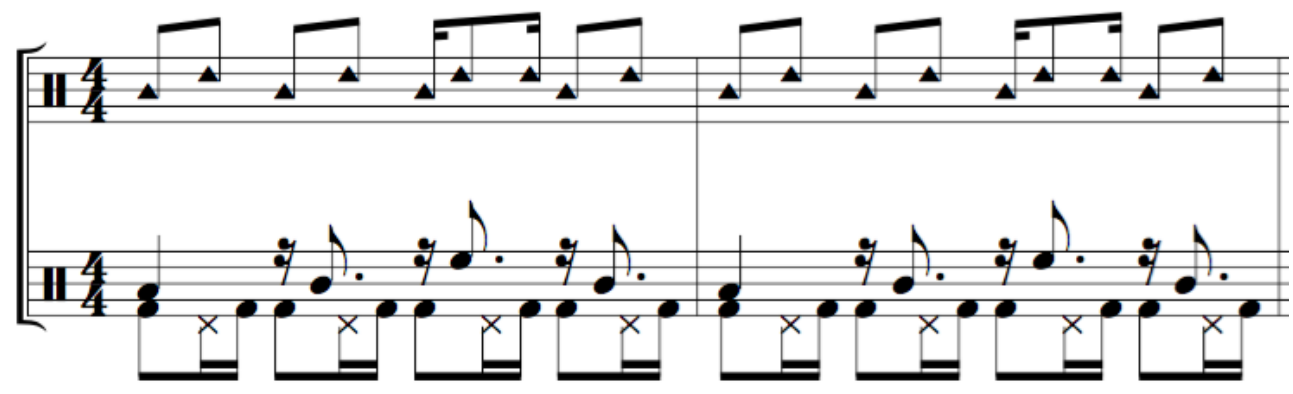

Figure 32 - Example 1 of Nenê's stylization of maracatu from his method book

In this case, even though one of the layers is commonly featured as a samba ostinato, the other patterns combined clearly characterizes the groove as a maracatu stylization. On the next example, the alfaia pattern is played on the bass drum and hihat, while an ostinato on the snare drum is added (Figure 33). 


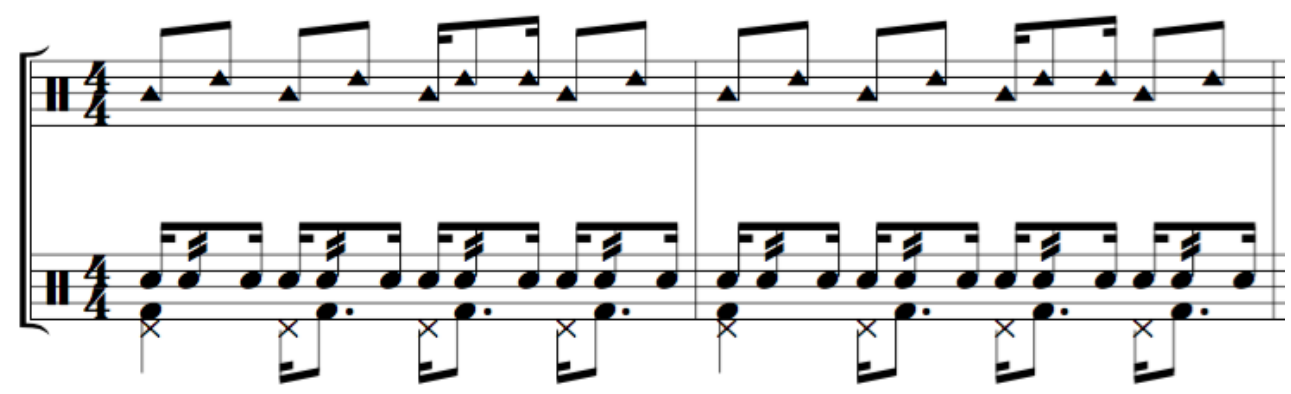

Figure 33 - Example 2 of Nenê's stylization of maracatu from his method book

\section{3 - Márcio Bahia's stylization of maracatu}

On the tune “Quiabo,” from the álbum Só Não Toca Quem Não Quer (1987), Bahia plays stylizations of maracatu on the drum by not straying from the source when exploring its patterns (Figure 34). While he plays characteristic maracatu patterns on the snare and bass drum, he adds variety by changing the placement of the hi-hat pattern. Also, this stylization is played in the context of a group that features another percussionist, who plays gonguê variations in a way that completes the colors commonly heard in maracatu percussion ensembles.
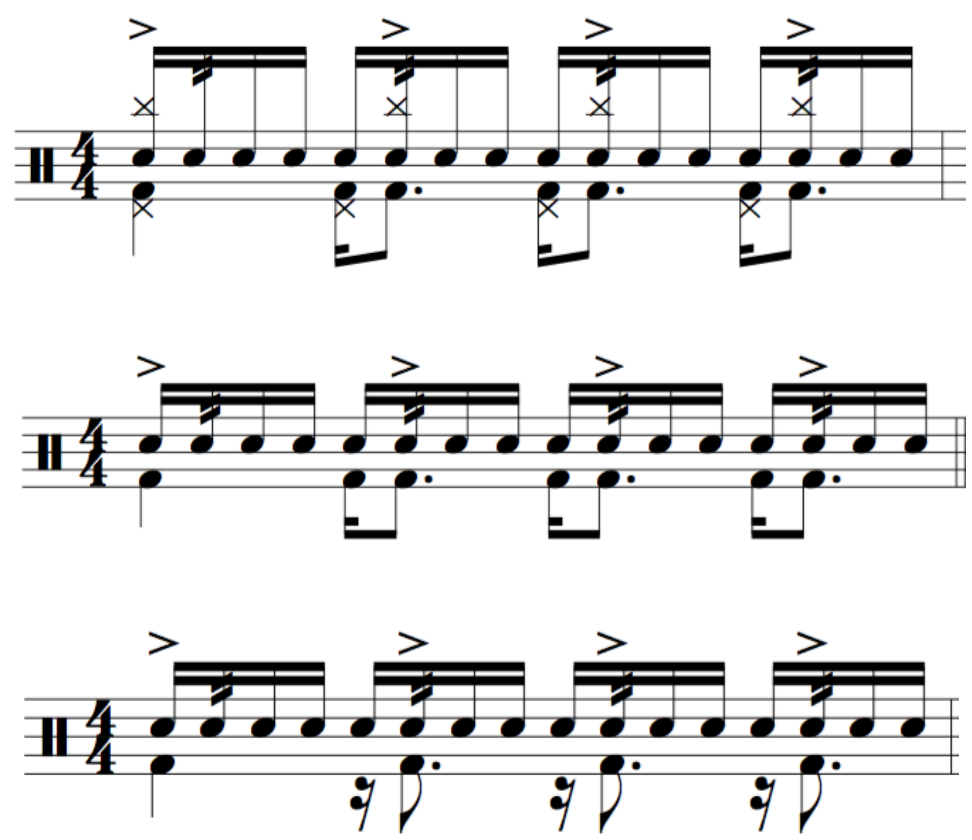


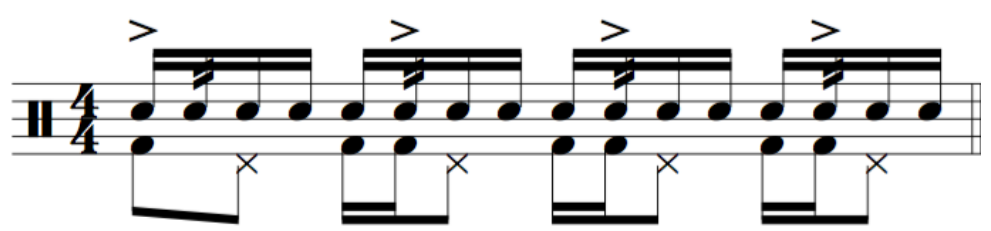

Figure 34- Bahia's stylization of maracatu on tune "Quiabo" 


\section{CHAPTER 5 - FREVO}

\section{1 - The genre frevo}

The musical roots of frevo are connected to European music, as the maxixe, polka-marcha, dobrado, modinha and galope. It is also derived from the repertoire of military bands based in the city of Recife during the second half of the $19^{\text {th }}$ century. Although the frevo comes from folk songs, the instrumental version of the melodies was always present during the carnival on the street parades. Since it emerged, this music has been performed by carnival street bands, and is strongly linked to dance. In the 1920s and 1930s, along the foundation and consolidation of the radio in Recife, the music genre frevo became nationally known as the representative of the urban popular culture from the state of Pernambuco. ${ }^{56}$

In their origin, the street bands from Recife consisted of two kinds differentiated by instrumentation and cultural influence. Both featured percussion ensembles, but some used brass instruments to play melodies, while others would feature plucked string instruments instead. Throughout its consolidation, the frevo have embraced musical characteristics from Brazilian culture, adding syncopation to European march. Meanwhile, influence from North American culture was assimilated as well, at first through recordings and later through the radio. For instance, Brazilian

${ }^{56}$ Leonardo Vilaça Saldanha, "Frevendo no Recife: A Música Popular Urbana do Recife e sua consolidação através do Rádio" (PhD Diss., Universidade de Campinas, 2008), 32 . 
composers from Pernambuco would use the term "one-step" on music scores to specify the rhythm feel they were looking for in the piece. Moreover, after being exposed to the music recorded by jazz orchestras and big bands in the USA, composers, arrangers and instrumentalists from Recife began to incorporate aspects of North American jazz instrumentation and improvisation into their practices. ${ }^{57}$

The subgenres of frevo differ mainly by the form, instrumentation and the place they are performed. The frevo performed on the streets during the carnival is called frevo-de-rua, it has flexible form and features saxes, brass instruments and percussion. The frevo-canção presents similar instrumentation to the frevo-de-rua, however it has a section with lyrics performed by a singer. The third sub-genre is the frevo-de-bloco, performed by percussion, woodwinds and string instruments such as the acoustic guitar, cavaquinho, banjo and bandolim.

Generally, the percussion section of any frevo orchestra consists of surdo (similar to a bass drum played with one stick and one bare hand), caixa (similar to the snare drum, played with sticks) and pandeiro (Brazilian tambourine). The section is composed by many members when performing on the streets, but is usually reduced to one drum set player plus one or two percussionists when it is part of a frevo orchestra that replicates North American big bands' format.

In any frevo subgenre, the percussion section performs the same basic groove, adding particular accents and phrases according to the composition or arrangement (Figure 35). ${ }^{58}$

${ }^{57}$ Leonardo Vilaça Saldanha, "Frevendo no Recife: A Música Popular Urbana do Recife e sua consolidação através do Rádio" (PhD Diss., Universidade de Campinas, 2008), 29.

${ }^{58}$ Ibid., 184. 


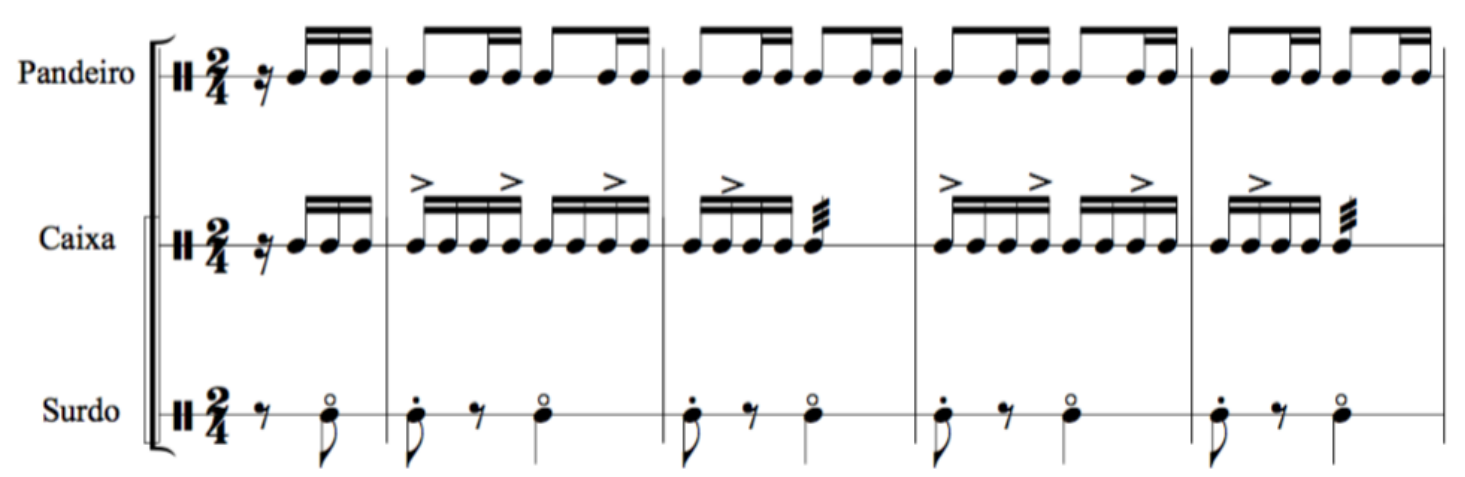

Figure 35 - Fundamental frevo groove played by percussion ensemble

Throughout the development of frevo as a musical genre, many musicians had added their contribution, and some placed their names in history by changing in some way the trend of this music. Some maestros and composers that were important to the genre during the $19^{\text {th }}$ and $20^{\text {th }}$ century were: Zuzinha; Nelson Ferreira; Capiba; Edison Rodrigues; Maestro Duda; Amélia Brandão Nery; Estefâna de Macedo; Osvaldo Santiago; Valdemar de Oliveira; Luperce Miranda; and Edgar Moraes. ${ }^{59}$ In addition to the contribution made by them, it is necessary to mention the names of Spok, Nilson Lopes, Ademir Araújo, José Menezes and Clóvis Pereira, since they represent a younger generation of composers, also very important to frevo as a musical genre.

\section{2 - Airto's stylization of frevo}

On the recording of the tune "Frevo de Itamaraca" from Edu Lobo's album Cantiga de Longe (1979), Airto played on the hi-hats the characteristic frevo pattern

${ }^{59}$ Leonardo Vilaça Saldanha, "Frevendo no Recife: A Música Popular Urbana do Recife e sua consolidação através do Rádio" (PhD Diss., Universidade de Campinas, 2008), 282. 
usually played on the snare, while another percussionist recorded the surdo to complete the groove (Figure 36).

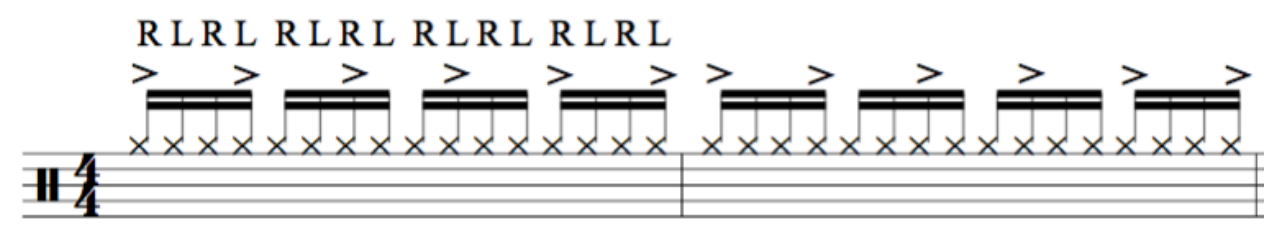

Figure 36 - Airto's stylization of frevo

\section{3 - Nenê's stylization of frevo}

This specific stylization of frevo is featured in many recordings by Nenê, including the tune "Alexandre, Marcelo e Pablo" from the Hermeto's album Zabumbe-Bum-Á (1979), and "Frevo" from the album Sanfona (1981). This groove is a good example of Nenê's effort to find simple ways of creating interesting stylizations on the drum set. To create a unique frevo stylization, Nenê only had to play the frevo snare pattern in two different pieces of the drum set, keeping the accent and ultimately creating one more layer to the groove. He also plays the bass drum, emulating the surdo pattern characteristic of frevo (Figure 37), and adds the hi-hat with the foot when playing the ride cymbal (Figure 38).

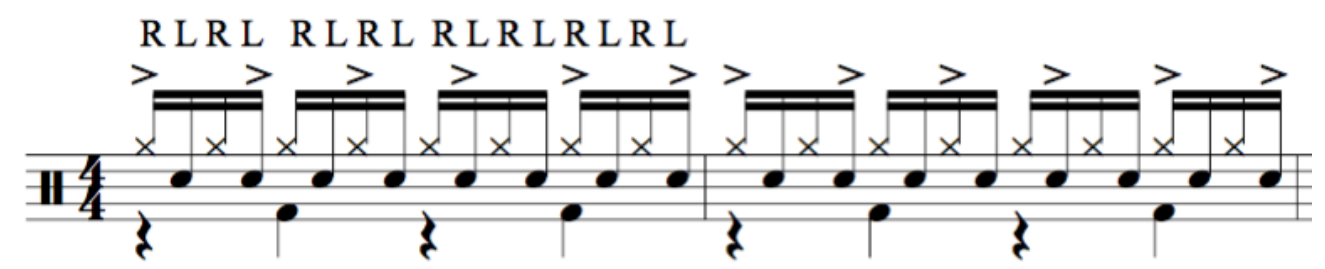

Figure 37 - Nenê's stylization of frevo 

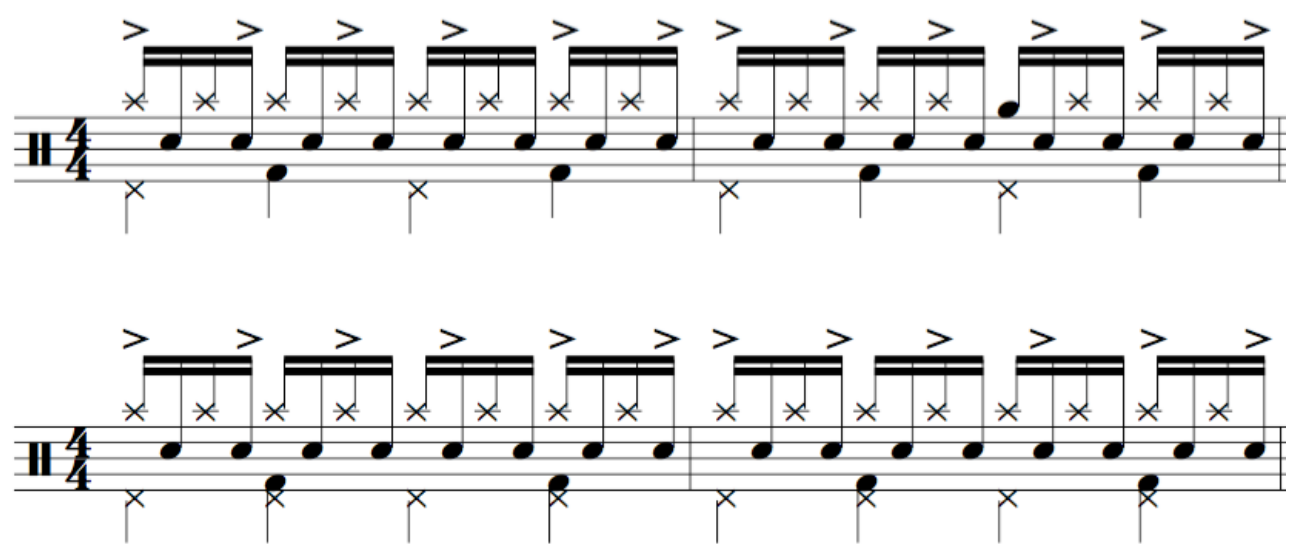

Figure 38 - Variations of Nenê's stylization of frevo

\section{4 - Márcio Bahia's stylization of frevo}

On the tune "Frevo em Maceió," recorded on the album Lagoa da Canoa Município de Arapiraca (1984), Márcio adds the ride cymbal to the frevo groove. In contrast to the stylization performed by Nenê, Bahia plays eight-notes on the cymbal, while featuring only the accents of the frevo pattern on the snare (Figure 39).

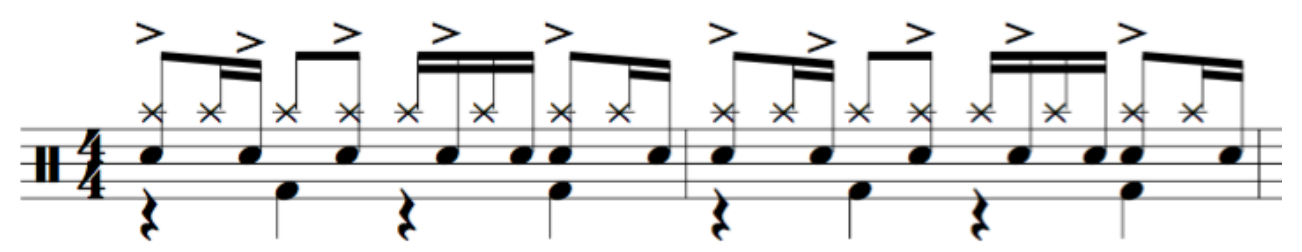

Figure 39 - Bahia's stylization of frevo

Bahia also applies variations to the hi-hat and ride pattern, using these layers to create contrasting densities while keeping the snare and bass drum patterns as the main characteristics of the groove (Figures 40 and 41). 

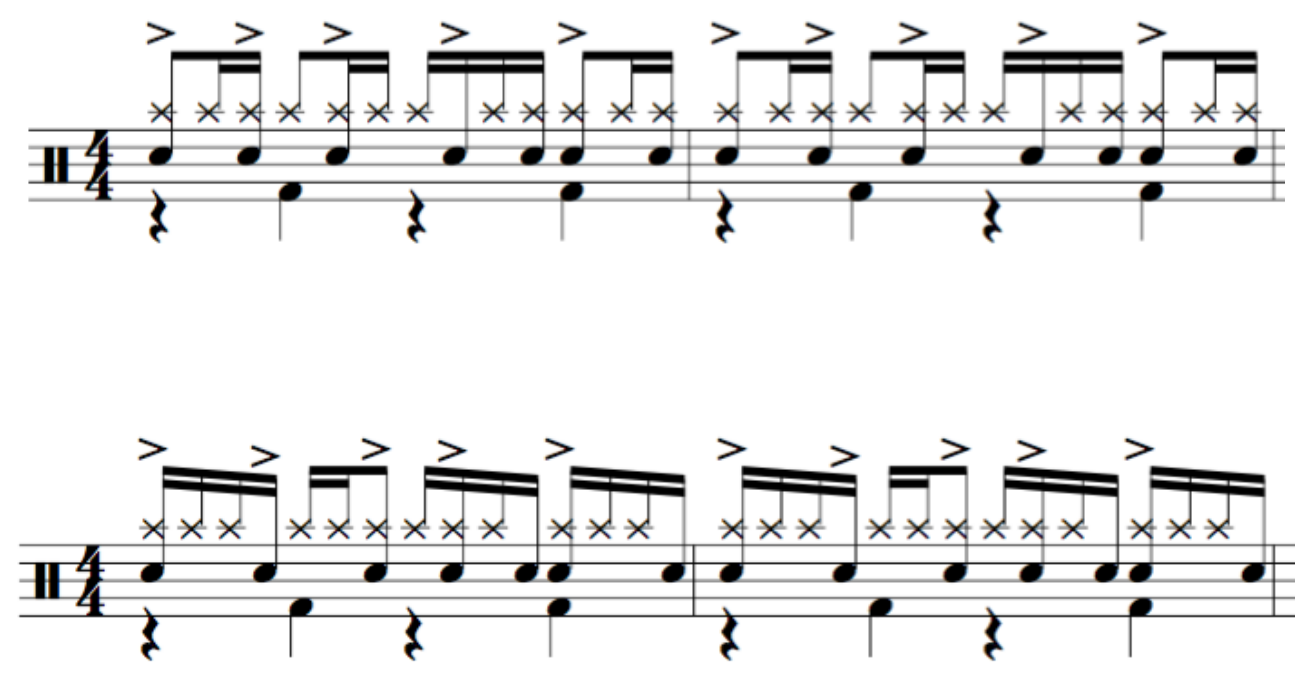

Figure 40 - Bahia's stylization of frevo
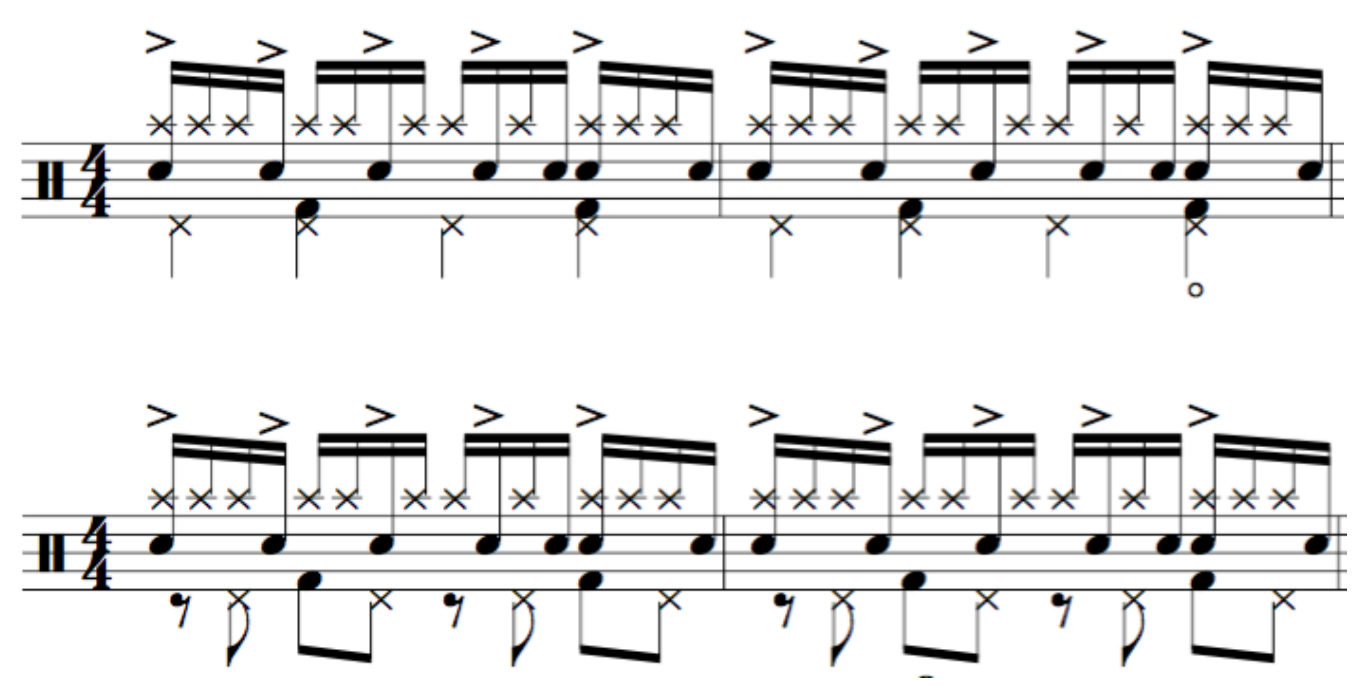

Figure 41 - Variations of Bahia's stylization of frevo 


\section{CONCLUSION}

The goal of this study has been to gain fundamental knowledge about the Brazilian music genres baião, maracatu and frevo, as well as an understanding of how to translate specific percussion ensemble grooves to the drum set. In addition to reviewing the origins of the samba and the North American influence in Brazilian culture, recollecting the path of the drum set in Brazil regarding the contributions of drummers, Luciano Perrone and Edison Machado, has been essential to understand the approach of stylization of Northeast Brazilian rhythms by contemporary drummers Airto Moreira, Nenê and Márcio Bahia.

After investigating the career of Airto, Nenê and Márcio, it is possible to affirm that, regarding the Brazilian drum set vocabulary, Hermeto Pascoal represents an important point of connection between the interactive musical approach of sambajazz and the musical genres of baião, maracatu and frevo.

Moreover, through the analysis of stylizations performed by the drummers mentioned in this thesis, it is fair to list some important insights about the task of successfully transposing Northeast Brazilian rhythms from percussion ensembles to the drum set. First, to the drummer interested in assembling his or her own stylizations of baião, frevo or maracatu into their vocabulary, it is crucial to listen to each genre's respective percussion ensemble as the original source, in addition to the stylizations previously made by other drummers. Second, it is important to identify the key patterns from the original source to be featured on the stylization. Regarding the maracatu, the ostinatos from the alfaia and the gongue are the most characteristic, 
followed by the snare pattern. For the baião stylization, the low notes from the zabumba frame the most important layer for distinguishing the xaxado, baião, xote and forró between each other. To play the frevo on the drum set, it is crucial to feature the pattern shaped by the characteristic accents of the snare drum. Third, combinations of baião, maracatu or frevo patterns with generic ostinatos common to the drummer's vocabulary are encouraged, and can be explored as an effort to create contrasting orchestration on the drum set within the style.

The technical solutions present through generations of drummers often become part of the instrument's vocabulary and are generalized to many genres' stylizations. As a result, complex rhythms and subtle colors and timbres can be lost as they are compressed into the drum set vocabulary. This problem is reinforced by the innumerable method books based in systems of coordination specific to the drum set. This scenario, combined with a superficial perception of rhythmic nuances, often leads arrangers and composers to refer to stylizations by using confusing or overly broad terms on drum set parts, for example: samba-funk, samba-rock, Latin, AfroCuban and Salsa. Finally, it is important to realize that a stylization on the drum set implies many factors such as the drummer's perception of the rhythms' source, technical limitations related to the drum set, as well as the choice of patterns, timbre, and the musical context in which the stylization is featured.

In the context of jazz and other music genres, the study of baião, maracatu and frevo stylizations is important not only for the drummer aiming to gain deeper knowledge and skills on Brazilian rhythms, but also to any musician willing to feature these genres on arrangements or compositions. Furthermore, the understanding of the richness contained behind these stylizations can represent to the performer an opportunity to take her or his musicianship to another level, as a player and as a 
listener. Also, being able to distinguish between these rhythms and point their main aspects, is fundamental to achieve a precise musical expression when writing arrangements or performing the respective styles.

Finally, it is important to note that the Brazilian styles presented in this research are current as music performed by percussion ensembles, which are featured in different cultural environments and generate a myriad of musical products. This also means that the interested musician might be able to find contemporary and older recordings featuring these rhythms, as well as to watch live performances of percussion ensembles strongly linked to their cultural roots. These observations bring up some questions that could lead to potential topics for further research, for example: Does the drum set help or disturb the existence and propagation of these rhythms in their original form? What is the role of the drum set in merging styles and rhythms? How are percussion ensembles influenced by the drum set stylizations of these rhythms? What are other folk rhythms current in the Brazilian jazz context? What are the general rhythmic aspects that could characterize or distinguish broadly the vocabulary of the Brazilian jazz drummer in relation to jazz drummers from other cultures? 


\section{REFERENCES}

Bryan McCann. Hello, Hello Brazil: Popular Music in the Making of Modern Brazil. Durham: Duke University Press, 2004.

Fabio Bergamini. "Márcio Bahia e a 'Escola do Jabour'.” Master Thesis, Universidade de Campinas, 2014.

Grove Music Online. "Drum set." Accessed Sep. 19, 2018.

http:///www.oxfordmusiconline.com/grovemusic/view/10.1093/gmo/978156 $\underline{1592630.001 .0001 / o m o-9781561592630-e-2000130700}$

Guilherme Marques Dias. “Airto Moreira: do Samba-jazz à Música dos Anos 70.” Master Thesis, Universidade de Campinas, 2013.

Ivaldo Marciano de França Lima. "Entre Pernambuco e a África. História dos Maracatu-nação do Recife e a espetacularização da Cultura Popular.” $\mathrm{PhD}$ Diss., Universidade Federal Fluminense, 2010.

Joana Martins Saraiva. “A Invenção do Samba-jazz: Discursos sobre a Cena Musical de Copacabana no Final dos Anos 1950 e Início dos Anos 1960.” Master Thesis, PUC-Rio, 2007.

Késia Decoté Rodrigues. "Música Popular Instrumental Brasileira (1970-2005): Uma Abordagem Subsidiada pelo Estudo da Vida e Obra de Oito Pianistas.” Master Thesis, Universidade Federal do Rio de Janeiro, 2006.

Leandro Barsalini. “As Sínteses de Edison Machado.” Master Thesis, Universidade de Campinas, 2009. 
Leandro Barsalini. "Modos de Execução do Samba na Bateria.” PhD Diss., Universidade de Campinas, 2014.

Leonardo Vilaça Saldanha. "Frevendo no Recife: A Música Popular Urbana do Recife e sua consolidação através do Rádio.” PhD Diss., Universidade de Campinas, 2008 .

Maracatu Nação Estrela Brilhante. "Baque Virado/ Toada (Maracatu Nação)." Instrumentos Populares do Nordeste. MPL 9.346, 1976. Vinyl.

Marcio Mattos Aragão Madeira. "A Contribuição da Música Tradicional do Cariri Cearence à Música Popular Brasileira por meio do Baião de Luiz Gonzaga.” PhD Diss., Universidad Complutense de Madrid, 2016.

Oscar Bolão. Batuque is a Privilege, Percussion in the Music of Rio de Janeiro. São Paulo: Lumiar Press, 2009.

Vinícius de Camargo Barros. "O Uso do Tamborim por Mestre Marçal: Legado e Estudo Interpretativo.” Master Thesis, Universidade de Campinas, 2015.

Wagner Simões. "Maracatu Leão Coroado.” Filmed 1987 at Recife, PE, Brazil. Video, 18:15. https://www.youtube.com/watch?v=M9cE ng39M 
APPENDIX I - DRUM SET NOTATION

$\underset{1}{*}$ Crash cymbal $*$ Ride cymbal

\begin{tabular}{|l|l|l|l|l|l|}
\multicolumn{1}{c}{ high woodblock } & \multicolumn{2}{c}{ Snare rim click } & \multicolumn{2}{c}{ Low woodblock } \\
\hline \hline & $\times$ & & \\
\hline
\end{tabular}

\begin{tabular}{|l|l|l|l|l|}
\multicolumn{2}{c}{ Mid tom } & Floor tom & Bass drum & hi-hat played with foot \\
\hline He & & & \\
\hline
\end{tabular}




\section{APPENDIX II - LIST OF MUSICAL EXAMPLES}

\section{SAMBA-BATUCADO}

Ritmo de Samba na Cidade - Orquestra da Rádio Nacional (1938)

Luciano Perrone playing drum set along the orchestra of the Radio Nacional - sambabatucado

https://www.youtube.com/watch?v=BPKFjBsJCAE

Batucada Fantástica - Luciano Perrone e Ritmistas Brasileiros

Drum set combined with percussion ensemble - samba-batucado

https://www.youtube.com/watch?v=448qADNPBCY

Bate Papo a Três Vozes - Radamés Gnatalli

Luciano Perrone playing drum set - samba-batucado

https://www.youtube.com/watch? $\mathrm{v}=\mathrm{H} 3 \mathrm{MsUd}-6 \mathrm{OnU}$

Remexendo - Radamés Gnatalli

Rare video of Luciano Perrone playing drum set - maxixe

https://www.youtube.com/watch?v=3aMmkWZfH5M

Cheio de Malícia - Radamés Gnatalli \& Quarteto Continental (1957)

Luciano Perrone playing drum set - samba-batucado

https://www.youtube.com/watch? $\mathrm{v}=\mathrm{CL} 1 \mathrm{Aw}$ meBrU\&list=OLAK5uy 1XsCibR6M9

$\underline{\mathrm{Kb} 5 \mathrm{vCvFG} 2 \mathrm{DjCT} \mathrm{TIR} 5 \text { 5p9s\&index }=6}$

Radamés Gnatalli Sexteto (1960)

Luciano Perrone playing drum set and percussion (audio)

On this album Luciano probably recorded overdubs of percussion instruments. It features samba-batucado and other rhythms as baião and xote

https:/www.youtube.com/watch?v=IdYP7eZqJPY

\section{SAMBA-DE-PRATO}

Quintessência - Edison Machado é Samba Novo (1964)

https://www.youtube.com/watch?v=fXbuatKKmSQ

Azul Contente - Rio 65 Trio

Edison Machado playing drum set

https://www.youtube.com/watch? $\mathrm{v}=\mathrm{f3juR} \mathrm{hnbU}$ 
Dom Um - full album (1964)

Dom Um Romão playing drum set

https://www.youtube.com/watch? $\mathrm{v}=\mathrm{pBWOUDNHc} 7 \mathrm{~g} \& \mathrm{t}=287 \mathrm{~s}$

Improviso Negro - Sambalanço Trio (1965)

Airto Moreira playing drum set

https://www.youtube.com/watch?v=fjzGTLuQVuI

Coalhada - Sambrasa Trio (1965)

Airto Moreira playing drum set

https://www.youtube.com/watch?v=LqoosAOwIFU

Muito a Vontade - full album by João Donato trio (1962)

Milton Banana playing drum set

https:/www.youtube.com/watch?v=1mMllxkOPvc

Balançando com Milton Banana Trio - full álbum (1966)

Milton Banana playing drum set

https:/www.youtube.com/watch?v=Ds6RCcf280A\&t=949s

Neurótico - J.T.Meirelles (recording from album Stories Told, by David Zinno's group Unisphere)

Rafael Barata playing drum set

https://www.youtube.com/watch?v=a3P8pC_s03A\&feature=youtu.be\&fbclid=IwAR2

OdV314263ib8kIw9PHhybI6gFTN3uiOWpdweGsd2pvyJnR8DgUhEKdXQ

Samba de Almeida - Fábio Torres

Celso Almeida playing drums

https://www.youtube.com/watch?v=8QGFDd88HO0

Garota de Ipanema - Antônio Carlos Jobim (performed and arranged by Trio

Corrente)

Edu Ribeiro playing drum set

https://www.youtube.com/watch?v=xCuVafcQeWc

\section{BAIÃO}

Vamos Xaxear - Luiz Gonzaga - Xaxado

Percussion ensemble

https:/www.youtube.com/watch?v=OYuK27Iut2A

Xaxado - Luiz Gonzaga - Xaxado

Percussion ensemble

https://www.youtube.com/watch? $v=$ wdgrpWQuYm0 
Na Casa de Anita - Dominguinhos feat. Hermeto Pascoal - forró

Percussion ensemble

https://www.youtube.com/watch?v=KVRbW8k69hQ

Quando Chega o Verão - Dominguinhos \& Elba Ramalho - Xote

Percussion ensemble

https://www.youtube.com/watch?v=1TY3DBpBAJs

Tenho Sede - Dominguinhos \& Gilberto Gil - Xote

Drum set - Robertinho Silva

https://www.youtube.com/watch?v=4YWcrWqgNEg

Abri a Porta - Dominguinhos \& Gilberto Gil - Xote

Drum set - Robertinho Silva

https://www.youtube.com/watch?v=uPeLjU1v_S0

Sete Meninas - Luiz Gonzaga feat. Dominguinhos - Forró

Perc. ensemble

https://www.youtube.com/watch?v=kq_CQCW_N1M

Sebastiana - Luiz Gonzaga - Forró

Perc. ensemble

https://www.youtube.com/watch?v=W3yNYGfWCtA

Paraxaxá - Luiz Gonzaga (1953) - Xaxado

Perc. ensemble

https://www.youtube.com/watch?v=QatB7OAMH2k

Arroio - Free (1972), Airto Moreira - Baião

Drum set + percussion overdub

https://www.youtube.com/watch?v=mMcypzTNZMQ

Arroio - Free (1972), Airto Moreira (alternate take) - Baião

Drum set

https://www.youtube.com/watch?v=ediozrK45Lk

Jazz sous les Pommiers (live 2012) - Hermeto Pascoal e Grupo, Márcio Bahia on drums

$42: 15=$ baião

$42: 30=$ xote

https://www.youtube.com/watch?v=7ShDz-6bBJg\&t=2369s

Hermeto Pascoal e Grupo feat. Dominguinhos (live 1979), Nenê on drums 
25:00 = baião

https://www.youtube.com/watch?v=TJm7lU-duaM

Vera Cruz - Hamilton de Holanda Quinteto (live 2017) - Márcio Bahia on drums https://www.youtube.com/watch?v=GaOI_HyqJ 8

\section{MARACATU}

Canival parade - Maracatu Nação Leão Coroado - Baque-virado https://www.youtube.com/watch?v=sG1jDgAcpL4

Carnival parade (2019) - Maracatu Cambinda Brasileira - Baque-solto https://www.youtube.com/watch?v=STIaLmj5MXU

Rehearsal - Maracatu Nação Estrela Brilhante - Baque-virado https://www.youtube.com/watch? $v=\mathrm{a}-3 \mathrm{Q} 1 \mathrm{KgHM} 3 \mathrm{~s}$

Maracatu - Egberto Gismonti (live) - Nenê on drums https://www.youtube.com/watch?v=FK56bGqffsg

Essa Foi Demais - Hermeto Pascoal e Grupo (live 1986) - Márcio Bahia on drums $6: 30$

https://www.youtube.com/watch? $\mathrm{v}=\mathrm{g} 3 \mathrm{sxSsdB}-\mathrm{xw}$

Maracatu Atômico - Nação Zumbi (live 2016) - Mangue beat https://www.youtube.com/watch?v=pYWfLGi8f3w

\section{FREVO}

Carnival parade in Olinda - Frevo-de-rua https://www.youtube.com/watch?v=tPC2w4-dmfw

Carnival parade in Recife - Frevo-de-bloco https:/www.youtube.com/watch?v=HB2aKViLd8I

Spok Quinteto

https:/www.youtube.com/watch? $\mathrm{v}=\mathrm{cO} 10 b y \mathrm{P} 6 \mathrm{QD} 4 \& \mathrm{t}=301 \mathrm{~s}$

Spok Frevo Orquestra

https://www.youtube.com/watch? $\mathrm{v}=$ su-BXJGTuJo\&t=573s

Maestro Spok + Jazz Sinfônica

https://www.youtube.com/watch? $\mathrm{v}=\mathrm{t}-\mathrm{hV} 2 \mathrm{fm} 7 \mathrm{LQ} \& \mathrm{t}=1218 \mathrm{~s}$ 
Frevo - Egberto Gismonti - Nenê on drums

https://www.youtube.com/watch?v=ruF67dPGg3Y

Frevo em Maceió - Hermeto Pascoal e Grupo - Márcio Bahia on drums

https://www.youtube.com/watch?v=1hk9XjbOIO8

Frevo de Itamaraca/Come e Dorme (1970) - Edu Lobo, Hermeto Pascoal, Airto Moreira

https://www.youtube.com/watch?v=9WPhQIOEXlo

Jazz sous les Pommiers (live 2012) - Hermeto Pascoal e Grupo, Márcio Bahia on drums

$1: 14: 25$

https://www.youtube.com/watch?v=7ShDz-6bBJg\&t=2369s 


\section{CURRICULUM VITA}

NAME: $\quad$ Lucas Gomes Maia Tomé Pimentel

ADDRESS: Cond. Side Home, 1a Avenida - 70, Apt. 305 - Set. Leste Vila Nova.

Goiânia-GO

$74643-070$

Brazil

DOB: $\quad$ Goiânia, GO (Brazil) October 18, 1989

EDUCATION

\& TRAINING: B.M., Music Education

Universidade Federal de Goiás

$2010-2015$ 